\title{
Pharmacological Targeting of Cell Cycle, Apoptotic and Cell Adhesion Signaling Pathways Implicated in Chemoresistance of Cancer Cells
}

\author{
Dauren Alimbetov ${ }^{1, *}$, Sholpan Askarova ${ }^{1}{ }^{(\mathbb{D})}$, Bauyrzhan Umbayev ${ }^{1}{ }^{(\mathbb{D})}$, Terence Davis ${ }^{2}{ }^{(\mathbb{D})}$ and \\ David Kipling ${ }^{2}$ \\ 1 Laboratory of bioengineering and regenerative medicine, Center for Life Sciences, \\ National Laboratory Astana, Nazarbayev University, 53 Kabanbay Batyr Ave, Z05H0P9 Astana, Kazakhstan; \\ shaskarova@nu.edu.kz (S.A.); bauyrzhan.umbayev@nu.edu.kz (B.U.) \\ 2 Division of Cancer and Genetics, Cardiff University School of Medicine, Heath Park, Cardiff CF14 4XN, UK; \\ davist2@Cardiff.ac.uk (T.D.); kiplingd@cardiff.ac.uk (D.K.) \\ * Correspondence: dauren.alimbetov@nu.edu.kz; Tel.: +7-7172-70-61-47
}

Received: 2 May 2018; Accepted: 1 June 2018; Published: 6 June 2018

\begin{abstract}
Chemotherapeutic drugs target a physiological differentiating feature of cancer cells as they tend to actively proliferate more than normal cells. They have well-known side-effects resulting from the death of highly proliferative normal cells in the gut and immune system. Cancer treatment has changed dramatically over the years owing to rapid advances in oncology research. Developments in cancer therapies, namely surgery, radiotherapy, cytotoxic chemotherapy and selective treatment methods due to better understanding of tumor characteristics, have significantly increased cancer survival. However, many chemotherapeutic regimes still fail, with $90 \%$ of the drug failures in metastatic cancer treatment due to chemoresistance, as cancer cells eventually develop resistance to chemotherapeutic drugs. Chemoresistance is caused through genetic mutations in various proteins involved in cellular mechanisms such as cell cycle, apoptosis and cell adhesion, and targeting those mechanisms could improve outcomes of cancer therapy. Recent developments in cancer treatment are focused on combination therapy, whereby cells are sensitized to chemotherapeutic agents using inhibitors of target pathways inducing chemoresistance thus, hopefully, overcoming the problems of drug resistance. In this review, we discuss the role of cell cycle, apoptosis and cell adhesion in cancer chemoresistance mechanisms, possible drugs to target these pathways and, thus, novel therapeutic approaches for cancer treatment.
\end{abstract}

Keywords: chemoresistance; cell cycle; apoptosis; cell adhesion; small molecules

\section{Introduction}

Chemotherapy remains the major treatment in cancer therapy, although the molecular mechanisms causing sensitivity or resistance to chemotherapeutic drugs in different tumor types are still unclear. Thus, determining the optimal chemotherapeutic regime for a given cancer type is problematic, and can result in very different outcomes for the individual. For instance, testicular cancers respond well to chemotherapy resulting in around $80 \%$ positive outcomes [1], while others, such as non-small cell lung cancer (NSCLC), have only a 30\% response rate to cytotoxic platinum based chemotherapy leaving the remaining $70 \%$ of patients with little to no benefit or, indeed, side effects related to drug toxicity [2]. Most chemotherapeutic agents cause DNA damage and activate a complex signaling network resulting in cell cycle arrest and/or apoptosis. During the course of tumorigenesis and tumor progression, nearly all cancer cells disrupt components of the DNA damage response (DDR) pathway [3]. The disruption to the DDR eventually leads to genomic instability that 
may underlie some aspects of cancer chemoresistance. Thus, the effectiveness of chemotherapy may depend upon DDR differences between normal and tumor cells $[4,5]$.

When DNA damaging agents are used to treat cancer, some clones within the cancer tissue up-regulate the expression of specific genes that either activate, or suppress, signaling networks regulating cell cycle arrest or DNA repair. These alterations may result in resistance of cells to drug-induced death signals. Consequently, this mechanism acts as a positive selection pressure in favor of recurrent tumors originating from drug resistant clones [6]. Thus, studying specific resistance mechanisms and developing new therapeutic strategies directed against these are extremely important in improving the effectiveness of chemotherapy and, hence, patient survival. In this review we focus on three main mechanisms involved in chemoresistance, alterations of which we believe will play an important role in improving the effectiveness of cancer therapy.

\subsection{Cell Cycle}

Regulation of the cell cycle by targeting cell-signaling pathways is a relatively new area for cancer treatment, and targeting cell cycle phases and checkpoints could provide unique opportunities and promise for the improvement of cancer treatment. Cell cycle progression has five known phases: G0 (gap 0), G1 (gap 1), S (DNA synthesis), G2 (gap 2), and M (mitosis). In between these phases are checkpoints at which times the integrity of cellular components and the fidelity of DNA synthesis are monitored. Two important checkpoints are at the G1/S and G2/M boundaries [7].

Tumor cells tend to accumulate alterations in components of the cell cycle machinery which results in an impaired ability to respond to DNA damage, in particular by halting cell cycle progression, and an abnormal distribution of cells during cell cycle progression is a hallmark of human cancer. As many anti-cancer drugs are DNA damaging agents, a reduced ability of the cell cycle machinery to respond to DNA damage may result in chemoresistance. To date, there are a number of cancer therapeutic strategies focused on cell cycle regulation. However, many of the proposed drugs failed to selectively kill cancer cells without also having major cytotoxic effects on normal cells; in other words, they had a small therapeutic window [7-9]. Therefore, a new generation of drugs targeting cell cycle features that are more specific to cancer cells is needed.

\subsection{Apoptosis}

Apoptosis is a mechanism of programmed cell death whereby cells with extensive DNA damage can be eliminated [10]. It was in the early 1970s when Kerr et al. first suggested that apoptosis could be vital for eliminating malignant cells, hyperplasia and tumor progression [10]. Therefore, triggering apoptosis in cancerous cells may play an important role in cancer therapy, and malignant tumor cells need to be selectively killed so healthy cells remain untouched for further proliferation [11]. However, another hallmark of cancer is the ability of tumor cells to avoid apoptosis during chemotherapy. There are three main known mechanisms by which cancer cells acquire apoptosis resistance: (1) a disruption in the balance between pro- and anti-apoptotic proteins, (2) an impairment of signaling through death receptors and (3) a reduction in the function of caspases [12]. Many strategies are being developed to target these pathways in order to counter chemoresistance mechanisms in cancer, and this is a fruitful field for further investigations.

\subsection{Cell Adhesion}

Cell adhesion is another mechanism essential for cell growth, cell migration and cell differentiation $[13,14]$. Cell adhesion is an interaction between individual cells, or between cells and extracellular matrix components, and important molecules involved in these interactions are the cellular adhesion molecules (CAMs). CAMs are implicated in processes as varied as cellular recognition and communication, signal transduction, embryogenesis, immunity, apoptosis and inflammation [15]. CAMs are thought to be involved in the development of metastasis as they contribute to the spread of metastatic tumor cells into the blood or lymphatic circulation due to the loss of intercellular adhesion, 
and there is strong evidence suggesting that CAMs could be associated with invasion in many human cancers [16,17]. The role of intercellular interaction in cancer cell survival during DNA damage due to radio or chemotherapy was first described by Durand and Sutherland [18]. These diverse functions identify CAMs as an attractive target for cancer therapy.

\section{Cell Cycle as a Target for Overcoming Chemoresistance during Cancer Therapy}

\subsection{Cyclins and Cyclin Dependent Kinases}

Cell cycle progression is regulated by cyclins through activating cyclin-dependent kinase (CDKs). CDKs are upregulated by cyclins (A, B, D and E) and downregulated by cyclin-dependent kinase inhibitors such as $\mathrm{p} 16^{\mathrm{INK} 4 \mathrm{a}}$ and $\mathrm{p} 21^{\mathrm{Cip} 1}$ [19]. To date, there are nine known structurally related CDKs (CDK1-CDK9) although their role in cell cycle has not been fully explored. Furthermore, CDKs play an important role in apoptosis and are up or downregulated in many cancers including lymphoma, lung cancer, leukemia, pancreatic tumors and hepatocellular carcinoma [20]. Several cyclins have been identified that control cell cycle progression via activation of CDKs. D-cyclins are activated in G1 phase to direct phosphorylation of the cell cycle inhibitor $\mathrm{pRb}$ which in turn inactivates regulatory functions of cells allowing their progression into $S$ phase. Cyclin E accumulates at the G1/S phase and activates CDK2, promoting progression through the G1 interval. Cyclin A promotes cell cycle progression through $\mathrm{G} 2$-accumulates during $\mathrm{S}$ and goes down during $\mathrm{G} 2$. Further, cyclin B and CDK1 interact to drive cells into mitosis [20,21].

Given the importance of the cyclins and CDKs for cell cycle control, these make attractive targets for chemotherapeutic intervention with pharmacological inhibitors (herein called CKIs) proposed for cancer treatment [22]. To date there are 11 known classes of CDK ATP competitive inhibitors, such as staurosporine, flavonoid, purine indole, pyrine, pyrimidine, indirubin, pyrazole, thiazole, paullone and hymenialdisine derivatives [23]. These CKIs target various cyclin/CDK complexes showing some positive results in vitro and in vivo. For example, the CKI, roscovitine, sensitized glioblastoma cells to tumor necrosis factor-related apoptosis-inducing ligand (TRAIL)-mediated apoptosis in vitro by targeting CDK2/cyclin B, E or A complexes [24] and milciclib inhibited cell proliferation, downregulated $\mathrm{CDK} 4 / \mathrm{Rb}$ transduction pathway markers, and induced cell death by autophagy through inhibition of CDK2/cyclin A, CDK7/cyclin H and CDK4/cyclin D1 complexes in glioblastoma cells [25].

First generation CKIs used in chemotherapy (e.g., flavopiridol) resulted in G1 or G2 phase cell arrest in vitro in hematological cancers as a result of CDK7 and CDK9 inhibition and showed good activity pre-clinically, although they possessed off-target toxicities in vivo, in particular neutropenia [26]. A positive effect for flavopirdol to enhance cytotoxicity in glioblastoma cells was observed when used in combination with temozolomide [27]. Resistance to temozolomide occurred due to activation of G2 checkpoint mediated DNA repair, although it was reported that CKIs prevented temozolomide resistance by suppressing the DNA repair mechanism at the G2/M phase of the cell cycle [27].

Further, the small molecule CGP 75414A induced cell cycle arrest and apoptosis in human leukemic cell lines, and caused a modest G2/M arrest, apoptosis via Poly(ADP-ribose Polymerase (PARP) cleavage and mitochondrial damage in U937 monocytic human cancer cells by inhibiting the activity of CDK2 and CDK4 [22]. In addition, novel small molecule derivatives (BA-12 and BP-14) of the roscovitine were shown to induce accumulation of hepatocellular carcinoma cells in $\mathrm{G} 2 / \mathrm{M}$ and S/G2 phases of the cell cycle, suggesting that both BA-12 and BP-14 possess antiproliferative activity [28]. These molecules did not cause resistance in several hepatoma cell lines and no enhanced viability of hepatocellular carcinoma cells was observed after long-term treatment [28].

It is important to note the role of nuclear factor kappaB (NF- $\mathrm{kB}$ ) in chemoresistance mechanisms involving Cyclin/CDK complexes [29]. NF- $\mathrm{KB}$ may induce chemoresistance by regulating the cell cycle and exerting anti-apoptotic properties. Some data has shown that inhibition of NF- $\mathrm{KB}$ activity suppresses cell cycle progression, cell anti-apoptosis (anti-apoptotic proteins Bcl-2, X-linked inhibitor of apoptosis (XIAP), and B-cell lymphoma extra-large (Bcl-XL) and chemoresistance by reducing the 
concentrations of cyclins $\mathrm{A}, \mathrm{B}$, and $\mathrm{D} 1$, and $\mathrm{CDK} 4$ and $\mathrm{CDK} 6$, the major proteins associated with cell cycle [29].

Overall, cyclins and CDKs represent promising targets that may potentially improve the efficacy of standard chemotherapeutic cancer agents when the latter are used in combination with novel CKIs.

\subsection{The DNA Damage Responsive p53 Pathway}

Tp53 is a tumor suppressor gene encoding p53 that regulates cellular proliferation and apoptosis by activating several molecular pathways [30]. Recent findings suggest that the p53 signaling pathway is involved in chemosensitization of cancer cells to DNA-damaging agents through DNA damage response sensors ataxia telangiectasia mutated protein (ATM) and ataxia telangiectasia and Rad3-related protein (ATR) and their downstream cell cycle regulator checkpoint kinases 1 and 2 (Chk1 and Chk2) [31-33]. Chk1 and Chk2 kinases differ in structure although they exert similar functions in mediating cell cycle in response to genotoxic stress. Cell cycle arrest upon DNA damage is regulated by the p53-p21-dependent G1 checkpoint [31] and the Chk1-Cdc25-dependent G2 checkpoint [32,33].

The role of p53 in cancer has been extensively studied [34-36]. The importance of p53 upstream activation mechanisms and the kinases ATM and ATR in regulating DNA damage in response to double-strand breaks is also well known [37]. However, the specific alterations in these genes that contribute to drug resistance during chemotherapy still remain obscure. p53 is an important tumor suppressive factor, mutation of which plays an important role in many drug resistant mechanisms. For example, p53 activates the ATP-binding cassette transporter MDR1 (multidrug resistance 1) to cause resistance. Tp53 mutations are also associated with elevated levels of MDR-associated protein 2 (MRP2) and breast cancer resistance protein (BCRP), as well as high glutathione levels. Glutathione conjugates cisplatin as a substrate of $A B C$ transporters, leading to cisplatin efflux and resistance [34,38]. High levels of NF- $\mathrm{kB} 2$, Fos proto-oncogene protein (FOS) and MYC proto-oncogene protein (MYC) and the transactivation of nuclear transcription factor $\mathrm{Y}$ (NF-Y) in tumors that have mutated Tp53, also result in chemoresistance by activating the expression of target genes involved in cell survival, signal activation, and apoptosis resistance [34].

A combination therapy therefore using two or more chemotherapeutic drugs or inhibitors to increase the sensitivity of cancer cells to chemotherapeutic drugs could be used to treat Tp53-mutated cancers. Such combination therapy is predominantly focused on p53-deficient cancer cells as Tp53 mutation causes G1 checkpoint impairment [35] therefore leaving cancer cells to rely on G2 checkpoint for DNA repair and survival. This opens new possibilities for using G2 checkpoint inhibitors as chemosensitizers for p53-deficient cancer cells [36,39] with several checkpoint kinase inhibitors being currently tested in clinical trials [40]. The clinical usage of one of the main checkpoint inhibitors, UCN-01, was limited due to its destruction by plasma proteins in vivo, therefore new small molecule inhibitors of Chk1 or Chk2 are needed that avoid this issue so as to test their therapeutic potential for sensitizing p53-deficient cancer cells [41]. The G2 checkpoint inhibitor CBP-93872 significantly blocks the activity of ATR and Chk1 phosphorylation induced by chemotherapeutic drugs oxaliplatin or cisplatin [42]. The effect of CBP-93872 was seen as suppression of the G2 checkpoint by inhibiting DSB-dependent ATR activation [43,44], possibly improving the effect of DNA damaging agents in p53-deficient cancer cells. This molecule may have a non-toxic effect on healthy cells with activated p53 and p21 pathways that may indicate CBP-93872 as an effective chemosensitizer when used in combination with chemotherapeutic drugs such as oxaliplatin, cisplatin, gemcitabine, or 5-FU [42].

The tyrosine kinase WEE1 is highly expressed in many cancer types and plays a role in cell cycle progression via the G2 checkpoint [45]. It is implicated in cancer cell survival in mutated Tp53 cells and its loss sensitizes such cells to chemotherapy with DNA damaging agents by increasing apoptosis. Chemosensitivity to agents such as cisplatin, gemcitabine and carboplatin was increased when used in combination with the WEE1 inhibitor MK-1775 (otherwise called AZD1775) with tumor growth being reduced in many cancer types; importantly, no additional toxicity beyond that seen with the DNA damaging agents alone was seen [46]. Currently clinical trials using MK-1775 in combination 
with paclitaxel (NCT02448329) and carboplatin-paclitaxel (NCT02513563) are in progress at this time for cancers as diverse as advanced gastric adenocarcinoma and metastatic solid tumors. MK-1775 is also in trials with taxol for ovarian cancer (NCT02272790, NCT02272790, NCT01357161) [47]. Thus, the above data suggest that targeting of molecular components of the G2 checkpoint may have therapeutic promise in G1 checkpoint defective Tp53-mutated cancers.

\subsection{Targetting Mutated $p 53$}

As mutated p53 status is a feature of many cancers, it makes an attractive target for therapy $[45,48]$. Some mutated p53 forms are very stable and heterodimerize with wild-type p53 and can act in a dominant negative fashion disrupting, or abrogating, most or all normal p53 functions, such as apoptosis or cell cycle arrest $[45,49,50]$. For example, p53 is degraded by the E3 ubiquitin ligase mouse double minute 2 homolog (MDM2) that is a target of p53 transactivation; however many mutated p53 isoforms do not induce MDM2 resulting in mutated p53 stability [51]. This suggests that directly targeting mutated p53 may be therapeutically effective in many cancers, and some animal models have revealed promising outcomes in tumor regression when wild-type p53 was reactivated in p53 mutated cancers [52]. Although difficult to achieve, the main treatment strategies to date focus on the destabilization or inactivation of mutated p53, or the reactivation of wild-type functions in the mutated p53 protein, such as cell cycle arrest or apoptosis [53]. In this regard, the anti-cholesterol statins deplete misfolded p53 [54], although this was found to be ineffective as a therapy when used to treat prostate cancer [55]. However, pre-clinical studies do show that reactivation of p53 can slow tumor progression making this type of approach worthy of further study [56].

The small molecule PRIMA-1 and its analog PRIMA-1MET (APR-246) restored mutant p53 to a wild-type conformation leading to expression of p53 targets involved in apoptosis, notably Bax, Noxa and Puma [57,58]. In vivo, APR-246 shows impressive apoptotic and cytotoxic effects in p53 mutated SCLC, breast cancer and multiple myeloma, with the drug well tolerated during Phase I/IIa clinical trials [59-61]. APR-246 is currently in combination therapy trials with cisplatin, carboplatin or azacytidine for oesophageal, ovarian and myeloid cancers, and results are awaited [45]. In addition, APR-246 when used in combination with the proteasome inhibitor carfilzomibin overcame the chemoresistance to carfilzomibin in triple negative breast cancer [62]. As mutated p53 affects protein homeostasis via the proteasome machinery that can inhibit tumor suppression, these results create opportunities to develop combination therapy using drugs to target mutant p53 with anti-proteasome inhibitors.

Missense mutations in p53 often result in gain-of-function p53 isoforms, thus leading to great interest in the discovery of small molecules that destabilize mutated p53, allowing wild-type p53 to regain its functionality. In this regard the active chemical component in peppers, capsaicin (that has known anti-tumor properties), resulted in the degradation of mutated p53 by activating autophagy and lead to cell death in NSCLC cells [63]. Many mutated p53 forms can stimulate mechanistic target of rapamycin (mTOR) and block autophagic processes that could otherwise be tumor suppressive, leading to anti-apoptotic and pro-proliferative responses in breast and pancreatic cancer [64]. This mTOR stimulation sensitized cancer cells to mTOR inhibitors such as everolimus. Another vegetable compound, phenethyl isothiocyanate, restored wild-type p53 and inhibited tumor growth in a xenograft model [65]. Although not yet used in clinical trials, such naturally occurring p53 restoring dietary compounds may be a valuable addition to the chemotherapeutic arsenal as their in vivo toxicity to normal tissue may be low.

An alternative mechanism to deplete cells of mutated p53 protein complexes is the use of small peptides that prevent the ability of mutated 53 to bind to target proteins, and such peptides enhanced the therapeutic effects of adriamycin and cisplatin by inducing apoptosis [66]. Destabilization of mutated p53 complexes could also be achieved in cancer cells using small molecules PK-083 and PK-7088, resulting in activation of pro-apoptotic Noxa expression and apoptosis [67]. 
The paragraphs above only give a taste of the possibilities of anti-mutated-p53 therapeutics for chemosensitization; however, these strategies are still at an early developmental stage, although they do show promise for the future.

\subsection{Aurora Kinase Signaling}

The next pathway of interest is Aurora-A kinase (AURKA), a member of the mitotic serine/threonine kinase family involved in mitosis and meiosis during cell proliferation. The known Aurora kinases (A, B and C) share similar amino acid sequences, but their subcellular localization and functions differ. All three Aurora kinases are involved in cell division; however, Aurora-A regulates cell cycle progression by regulating the spindle and mitotic checkpoints. Its main functions are mitotic regulation, promotion of mitotic entry, and cell growth arrest [68]. Overexpression of Aurora-A is linked to breast, ovary, and colon tumors and is shown to act as an oncogene in many in vitro models [69]. Moreover, overexpression of Aurora-A has been associated with radio- and chemoresistance in laryngeal cancer cells [70], cervical cancer [71] and breast cancer [72]. Aurora-A has been suggested to induce chemoresistance in several cancers by reducing apoptosis via activation of the NF- $\mathrm{kB} / \mathrm{miR}-21 / \mathrm{PTEN}$ (phosphatase and tensin homolog) signaling pathway [73] and Akt through inhibition of the p53/PTEN cascade [74]. In addition, Sun et al. [75] have demonstrated that Aurora-A can induce radio- and chemoresistance through ATM/Chk2-mediated dysregulation of DNA damage repair networks including pp53, $\gamma \mathrm{H} 2 \mathrm{AX}$, and RAD51. These findings suggest Aurora-A kinase as a possible drug target to improve the outcomes of cancer therapy in many cancer types.

Aurora-A kinase inhibitors currently used in preclinical and clinical studies include MLN8054, PF-03814735, AS703569, MK-0457, MK-5108, MSC1992371A and MLN8237 [68]. Among these small molecule inhibitors MLN8237 was effective in treating acute myelogenous leukemia and chronic myelogenous leukemia in Phase II trials when used in combination with cytarabine [76] and nilotinib [77]. Another Aurora-A kinase inhibitor, MK-5108 (Phase I), inhibits cell growth and induces $\mathrm{G} 2 / \mathrm{M}$ arrest in chemoresistant epithelial ovarian cancer stem cells by affecting the NF- $\mathrm{kB}$ pathway [78]. Aurora kinase is a key player in mitosis and cancer and has attracted much attention as a therapeutic target for the treatment of leukemia and many other solid tumors [68]. More studies are needed to focus on the further usage of Aurora kinase inhibitors combined with conventional therapies to establish the most effective inhibition dosages.

\subsection{BRCA1/2}

The tumor suppressor genes $B R C A 1 / 2$ are frequently mutated in familial breast and ovarian cancer, and around $10 \%$ of women diagnosed with these pathologies carry BRCA1/2 mutations [79]. Furthermore, carriers of $B R C A 1 / 2$ mutations were reported to be at increased risk of developing pancreatic and prostate cancers [80]. The BRCA1/2 proteins are involved in several cellular mechanisms such as cell cycle checkpoint control, chromosome remodeling, transcriptional regulation, DNA repair, and apoptosis [79,81]. Additionally, BRCA1/2 are essential for both S and G2/M checkpoints in response to DNA damage caused by either radio or chemotherapy, and play important roles in multiple DNA repair pathways such as homologous recombination (HR) and transcription-coupled nucleotide excision repair (TCNER) [79,81,82].

Therefore, BRCA1/2-null cancers are more sensitive to platinum-based DNA damaging agents and to PARP inhibitors $[83,84]$. Nevertheless, these $B R C A 1 / 2$-null cancers develop resistance over time due to restored BRCA1/2 functions, as secondary mutations of $B R C A 1 / 2$ occur in $B R C A 1 / 2$-mutated tumors [85]. An inability to repair DNA makes cells sensitive to DNA damaging drugs, and restoration of DNA repair functions results in acquired resistance to those drugs [86]. It has been suggested that mutations in p53 upregulate BRCA1 and induce resistance to cisplatin in breast cancer. Further, BRCA1 can activate the transcriptional target TDP2 that pairs with ETS2 and mediates etoposide resistance in mutp53-bearing cells [34]. Studies carried out by Wiltshire et al. [87] revealed that BRCA1 
contributes to irofulven (6-hydroxymethylacylfulvene) chemoresistance, an anticancer agent derived from mushroom produced illudin toxins [87].

These established characteristics of BRCA1/2 proteins in chemoresistance indicate that new drugs are needed for BRCA1/2 inhibition, as known effective small molecules only affect BRCA1 indirectly. For example, inhibition of the homologous recombination (HR) pathway proteins RAD52/51 with small molecule D-I03 can specifically inhibit the biochemical activities of RAD52 and suppress growth of BRCA1 and BRCA2 null cells [88]. Likewise, PARP inhibitors (e.g., talazoparib, niraparib, olaparib, and veliparib) are also capable of sensitizing tumor cells with impaired HR activity by genomic instability and cell death. Since BRCA1 and BRCA2 mutated cells lack HR pathways, such inhibitors improve the effectiveness of chemotherapy in breast and ovarian cancer treatment [89].

\subsection{Wingless (WNT) Signaling}

WNT family proteins are essential for regulating diverse cellular mechanisms including cell proliferation, survival, migration and polarity, as well as cell fate specification and stem cell self-renewal [90]. Two main categories of WNT pathways have been identified to date: canonical WNT signaling (1) dependent on the transcriptional activity of $\beta$-catenin and non-canonical WNT signaling (2) which lacks $\beta$-catenin transcriptional activity [91]. WNT5A is a non-canonical member of the WNT family and is a tumor autocrine/paracrine factor highly expressed in many cancer types [91]. Upregulation of WNT5A is associated with breast cancer [92], prostate cancer [93], melanoma [94] and pancreatic cancer [90], indicating its oncogenic role in these cancers.

However, WNT5A is thought to induce chemoresistance in pancreatic cancer through enhanced PI3K/Akt signaling that affects the G1/S phase transition [90]. Furthermore, WNT5A was highly expressed in BRAF inhibitor (BRAFi)-resistant melanoma tumors [95]. The drug resistance mechanism appears to be that high levels of WNT5A activates signaling through Fzd7 and Ryk receptors that induce PI3K/Akt signaling resulting in increased growth and therapeutic resistance to BRAF inhibitors [95]. Further, WNT5A activates the WNT/protein kinase C (PKC) signaling pathway that is highly expressed in many cancers and causes chemoresistance by partly activating $W N T / \beta$-catenin signaling [96]. This was confirmed by in vitro studies where the PKC inhibitor GF109203X significantly inhibited WNT5A induced cell migration, invasion, and clonogenicity in A549 and A549/DDP (diamminedichloroplatinum) lung cancer cells, indicating a clear WNT5A role in promoting lung cancer cell mobility through WNT/PKC noncanonical pathway activation [97].

A recent study using WNT5A knockdown showed an increase of cells in G0/G1 phase and a decreased cell number in S phase, which enhanced the chemosensitivity of pancreatic cancer cells to gemcitabine [90]. Another study reported that WNT5A contributed to drug-resistance by enhancing anti-apoptosis ability in pancreatic cancer cells [98]. Since gemcitabine is a cell cycle specific drug, these studies have found that WNT5A mediated gemcitabine chemoresistance was via the regulation of cell cycle, which suggests WNT5A as an effective gemcitabine chemoresistance predictor and a target for chemotherapeutic response in pancreatic cancer.

\subsection{The p38 MAP Kinase Pathway}

The p38 mitogen activated protein kinases (herein called p38) are a family of serine/threonine kinases classified as "stress-activated" kinases in response to a variety of extracellular stimuli in different organisms. Immediate downstream of p38 is mitogen-activated protein kinase activated protein kinase 2 (MAPKAPK-2 or MK2), a kinase involved in inflammatory responses, cell division and differentiation, apoptosis, and cell motility [6]. p38 is involved in apoptotic cell death and key molecules in the apoptotic onset (e.g., Bcl-2 superfamily members or p53) have been shown to be p38 substrates [99,100]. Furthermore, MK2 is activated after DNA damage [101,102] resulting in cell cycle arrest and ultimately cellular senescence. These characteristics of p38 and MK2 make them attractive targets for chemotherapy considering that apoptosis and DNA repair are the main mechanisms associated with cell survival during DNA damage [103], thus a possible role in cancer treatment is being explored [104]. 
Many cancer cells have abrogated G1 checkpoints due to lesions in tumor suppressor molecules such as p53 that regulate cellular senescence that can be a response to DNA damaging agents [35]. Nevertheless, such cancer cells often retain a G2 checkpoint, in particular a chromatin-quality checkpoint in late G2 involving ATR/p38/MK2 [101,102,105,106]. Genetic disruption of the p38/MK2 pathway can specifically sensitize p53-null mouse cells to DNA damaging agents $[107,108]$. It seems that p53-null cells with abrogated p38/MK2 pathways have lost both G1 and G2 DNA damage checkpoint function and enter mitosis in the presence of DNA damage, where they die by "mitotic catastrophe". In contrast, p53 wild-type cells can still arrest in response to DNA damage as the p53-dependent G1 checkpoint is still active. These cells halt in G1 and do not enter into mitotic catastrophe. This suggests that small molecule targeting p38 or MK2 may result in sensitizing tumor cells to chemotherapeutic drugs.

Several p38 and MK2 inhibitors have been tested for their ability to increase the effectiveness of chemotherapeutic agents. For example, p38 activity was inhibited in gastric cancer cells (BGC823) using SB203580 that improved the sensitivity BGC823 cells to doxorubicin and induced cell death [109]. Furthermore, co-treatment with SB202190 and irinotecan improved the sensitivity of chemoresistant colorectal cancer cells to chemotherapy [110], and a p38 $\alpha$-selective MAPK inhibitor SCIO-469 reduced tumor growth in multiple myeloma xenograft tumors by enhancing the effect of bortezomib [6]. The MK2 pathway has been less studied compared to p38, however, some data suggest that the MK2 inhibitor MK2.III increases the sensitivity of pancreatic cancer cells to gemcitabine [111], and recent data show that MK2 knockdown reduces in vivo growth of multiple myeloma in mouse models with MK2 overexpression leading to bortezomib and doxorubicin chemoresistance by reducing apoptosis [112]. All these data suggest a role for p38 and MK2 in chemoresistance making them attractive targets for further research.

\section{Anti-Apoptotic Mechanisms in Resistance to Chemotherapy}

\subsection{Apoptotic Cell-Signaling Pathways}

There are two primary apoptotic cell-signaling pathways: extrinsic and intrinsic (Figure 1). The extrinsic pathway is triggered via interaction of cell surface death receptors, including CD95 (First apoptotis signal receptor/apoptosis antigen-1 [FAS-R/APO-1]), tumor necrosis factor-receptor (TNF-R) and TRAIL-receptors (TRAIL-Rs) with their death ligands, CD95L, TNF, or TRAIL [113]. Binding of death ligands leads to the formation of the death-inducing signaling complex (DISC) that involves the sequential recruitment of FAS associated protein with death domain (FADD) and pro-caspases to the receptor cytosolic domain, and subsequent activation of initiator caspases (e.g., caspase-8, caspase-10) [113]. Once activated, initiator caspases trigger downstream effector caspases (caspase-3, -6 , and -7 ) that, in turn, cleave vital cellular proteins responsible for the characteristic biochemical and morphological hallmarks of apoptosis [114].

The second pathway leading to programmed cell death is the intrinsic mitochondria-dependent apoptotic pathway (Figure 1). The essential initiators of this pathway are the BH3-only proteins Bid, Bim, Puma, Noxa, Bad, Bmf, Hrk, and Bik. Upon activation by intracellular stimuli, such as excessive ROS, DNA damage, and the unfolded protein response, BH3-only proteins translocate to mitochondria and activate the pore-forming Bax/Bak proteins at the mitochondrial outer membrane [115]. This leads to membrane permeabilization and the release of second mitochondria-derived activator of caspase/Direct Inhibitor of Apoptosis-Binding protein with Low pI (Smac/DIABLO) and cytochrome-c from the inter membrane space into the cytoplasm. Bax/Bak is also activated by caspase- 8 via the BH3-only protein tBID [116]. The release of cytochrome-c binds to the cytosolic proteins Apaf-1 and pro-caspase- 9 to facilitate the formation of the apoptosome. The apoptosome activates initiator caspase-9 and, consequently, effector caspases, thus triggering apoptosis [115]. A second protein released from the intermembrane space, Smac/DIABLO, suppresses the inhibitor of apoptosis proteins (IAPs) that negatively regulate the activity of initiator and effector caspases [117]. 
However, in malignant cells, intrinsic or acquired up-regulation of anti-apoptotic mechanisms and/or down regulation of pro-apoptotic molecules allows cancer cells to escape apoptosis and develop resistance to chemotherapy [103]. This resistance is a complex phenomenon that involves the interactions of various molecules and signaling pathways. In this section we discuss several anti-apoptotic mechanisms contributing to chemotherapy resistance in cancer cells, and pharmacological approaches that may help to increase susceptibility of tumors to anti-cancer treatment.

One of the cytokines associated with apoptosis and expressed in various tissues is TRAIL, a protein related to the superfamily of tumor necrosis factors. Death receptors DR4 and DR5 in cancer cells have high-affinity binding of TRAIL and their receptor/ligand interactions induce extrinsic apoptotic cell-signaling pathway [118]. In comparison with CD95/CD95L and TNF $\alpha /$ TNF-R this ligand cannot provoke immunoinflammatory response as lethal septic shock like side effect. In addition, the CD95/CD95L and TNF $\alpha$ /TNF-R1 have been reported to activate the oncogenic NF- $\mathrm{kB}$ pathway, while TRAIL has no, or a weak, effect on NF- $\mathrm{kB}$ activation and, therefore, it is considered a prospective chemotherapeutic agent [119]. However, TRAIL therapy is limited by resistance in a large number of cancer cells due to intrinsic or acquired downregulation of TRAIL-Rs [120] and sensitization of TRAIL/TRIAL-Rs axis via different cellular mechanisms of great clinical interest.

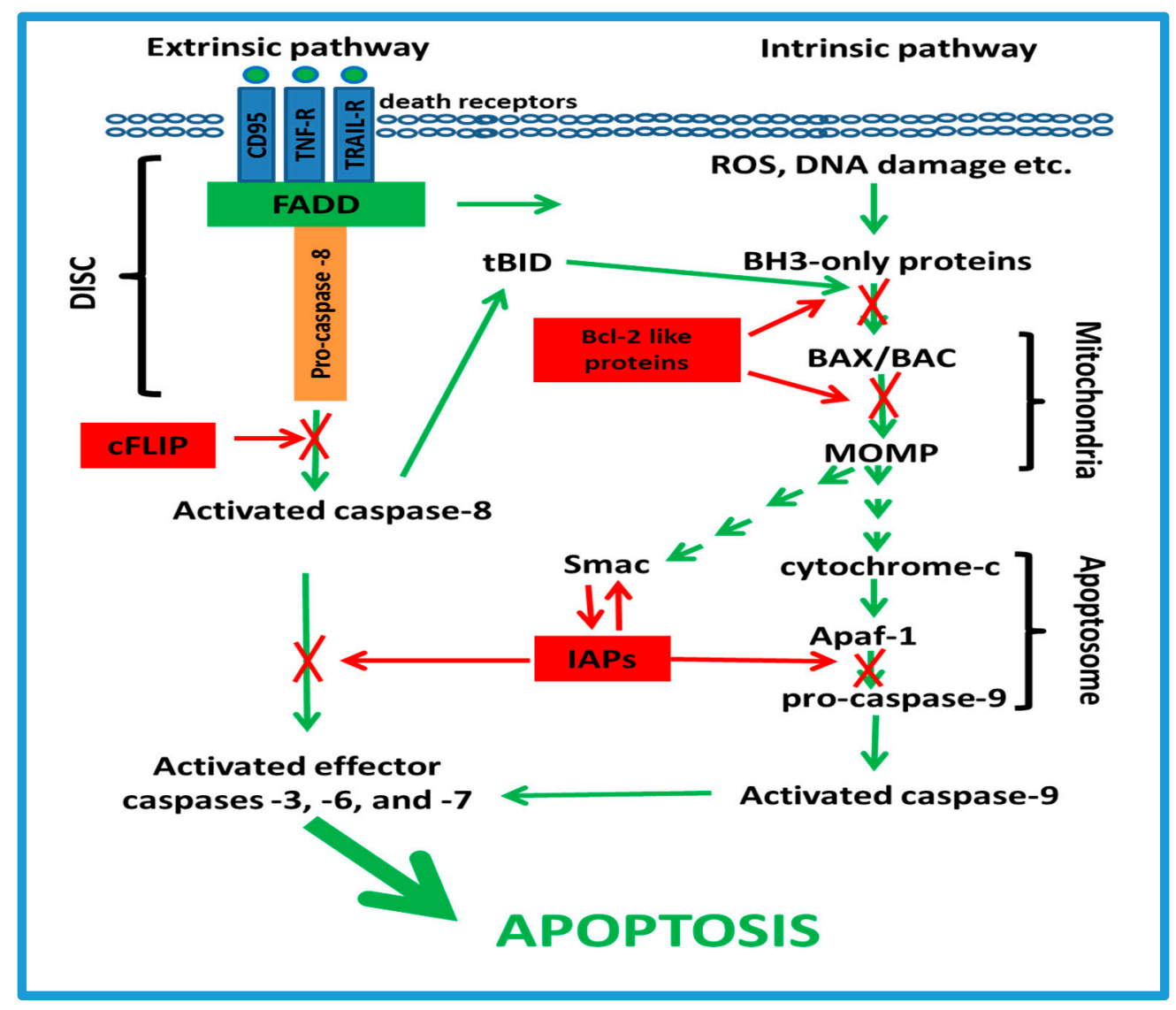

Figure 1. Anti-apoptotic mechanisms contributing to chemotherapy resistance in cancer cells. Extrinsic apoptotic pathways in tumors may be suppressed by downregulation of cell surface death receptors or/and overexpression of cFLIP; intrinsic (mitochondrial) apoptosis is blocked by up-regulation of Bcl-2-like proteins, and both pathways can be terminated by IAPs. FADD-FAS associated protein with death domain; DISC — the death-inducing signaling complex; cFLIP—the cellular FLICE (caspase 8)-like inhibitory protein; tBID—-truncated Bid protein; MOMP—mitochondrial outer membrane permeabilization; Smac — second mitochondria-derived activator of caspases; Apaf 1 -apoptotic protease activating factor 1; IAPs-inhibitor of apoptosis proteins. TRAIL. Note: green arrows-activation, red arrows-suppression, $\mathrm{X}$-blocking. 
For example, monesin, medicarpin, diallyl trisulfide, tunicamycin, and 5,7-dimethoxyflavone initiated up-regulation of death receptor 5 (DR5) in glioma, myeloid leukemia, human melanoma and hepatocellular carcinoma cells via the unfolded protein response [121-125]. Addition of proteasome inhibitor PS-341 (VELCADE, bortezomib) sensitized prostate cancer cells to TRAIL-induced apoptosis by increasing DR5 inhibiting protein degradation, and elevating DR5 mRNA [126]. TRAIL-resistant prostate cancer cells, glioma and HeLa cells have also been sensitized by inhibition of heat shock proteins 90 and 27 with geldanamycin, and small molecules 17-AAG and LY303511 [127-129]. In addition, targeting p53 [130], autophagy [131], protein synthesis [132] and epigenetic modulation [133] by different agents have been reported to increase sensitivity of breast, myeloid, lung, brain, skin, cervical and colon cancer cells to TRAIL therapy.

\subsection{The cFLIP Proteins}

Besides FADD and the procaspase-8, the cellular FLICE (caspase 8)-like inhibitory proteins (cFLIP) can be recruited to the DISC (Figure 1). Three human cellular homologs of cFLIP have been identified: c-FLIP(L), c-FLIP(S) and c-FLIP(R), which are generated by differential splicing [134]. Unlike procaspase-8, cFLIP proteins lack a catalytic cysteine in their active center, but are capable of binding to FADD and/or caspase- 8 or -10 in a ligand-dependent manner and preventing further activation of the caspase cascade $[135,136]$ (Figure 1). Upregulation of cFLIP has been shown in various cancer cells and is implicated in chemoresistance in response to various anticancer drugs [137-141]. In turn, inhibition of c-FLIP can significantly improve susceptibility of malignant cells to chemotherapy.

It has been demonstrated that chemoresistant murine thymoma cell lines were sensitized to CD95-induced apoptosis by cycloheximide via downregulation of cFLIP(L) [136]. Similarly, the motif chemokine (CXC) chemokine receptor (CXCR2) antagonist Z10397767 attenuated interleukin-8 (IL-8) induced c-FLIP(S) up-regulation in prostate cancer cell lines thus enhancing sensitivity of these cells to TRAIL-chemotherapy [142], and thioridazine increased susceptibility of head and neck squamous cell carcinoma cells (AMC-HN4) to carboplatin through downregulation of c-FLIP and Mcl-1 expression [143]. Additionally, it has been demonstrated that degradation of c-FLIP by the histone deacetylase inhibitor LBH589 and a steroidal lactone from Physalis peruviana Withanolide E mediated sensitization of pancreatic cancer cells and renal carcinoma cells to TRAIL-induced apoptosis $[144,145]$ (Table 1).

\subsection{The Bcl-2-Like Proteins}

The intrinsic pathway can be suppressed by overexpression of pro-survival Bcl-2-like proteins such as Bcl-2, Bcl-XL, Bcl-W, Mcl-1 and Bfl-1/A1 [146-148]. In turn, there is data indicating that suppression of Bcl-2-like proteins leads to the activation of apoptosis in chemoresistant cancer cells (Table 1), whereas their up-regulation in tumor cells is associated with poor prognosis and resistance to chemotherapy [146-148]. For example, inhibition of Bcl-2 and Bcl-XL by the small molecule compound ABT-737 significantly increased the number of apoptotic cells without affecting proliferation in human colorectal tissue cultured ex vivo [148]. Similarly, the small molecule Bcl-2-like protein inhibitor ABT-263 (navitoclax) exhibited single-agent antitumor activity in murine models of small cell lung cancer, leukemia, and lymphoma, and enhanced cytotoxicity when used with docetaxel or erlotinib in xenograft models [147]. Furthermore, the small molecule S63845 that specifically binds to Mcl-1 activates the Bax/Bak-dependent mitochondrial apoptotic pathway in myeloma, leukemia and lymphoma cells $[149,150]$. There is also data indicating that the small molecule ML214 (4-chloro-1-methyl-3-nitroquinolin-2-one) induces caspase activation in mouse embryonic fibroblasts (MEFs) overexpressing either A1-2A-BIM or A1 and alternate pro-apoptotic Bcl-2 protein tBID. In addition, this compound induces caspase activation and cytochrome $c$ release in human melanoma cell line expressing A1-2A-BIM [151]. 


\subsection{The IAP Family}

Another large group of proteins implicated in cancer cell apoptotic resistance are the inhibitors of apoptosis proteins (IAP) family [152-155]. There are eight members of this family identified in humans: neuronal IAP/NAIP (BIRC1); cellular IAP1, also called cIAP1/HIAP2 (BIRC2); cellular IAP2, also called cIAP2/HIAP1 (BIRC3); X-linked IAP/XIAP/hILP (BIRC4); Survivin (BIRC5); BIR containing ubiquitin conjugating enzyme/BRUCE/Apollon (BIRC6); Melanoma IAP/ML-IAP/Livin (BIRC7); and IAP-like protein 2/hILP2/Ts-IAP (BIRC8). The IAPs regulate the activity of initiator and effector caspases [117], and suppression of IAPs can augment the apoptotic effect of chemotherapeutics for many types of cancer cells (Table 1 ).

Moon et al. have shown that the novel small-molecule ZAD5582 promoted TNF- $\alpha$-induced apoptosis through targeting cIAP1 and XIAP in human pancreatic cancer cells [156]. AEG35156, a novel second-generation antisense oligonucleotide directed towards XIAP, increased sensitization of pancreatic carcinoma cells to TRAIL-mediated apoptosis as a single agent and was capable of inducing complete tumor regression when combined with taxanes in three human cancer xenograft models (prostate, colon, and lung) [157]. A Phase I clinical trial of AEG35165 demonstrated clinical evidence of its antitumor activity in patients with advanced refractory cancers [158]. Gyuraszova et al. have demonstrated that the small-molecule YM155, which is an inhibitor of BIRC5 (survivin), was capable of potentiating the cytotoxic effect of hypericin-mediated photodynamic therapy (HY-PDT) in two cell lines resistant to HY-PDT, HT-29 (colorectal adenocarcinoma) and A549 (lung adenocarcinoma) [159].

As mentioned, the Smac/DIABLO is a second protein released from the intermembrane space upon the outer membrane permeabilization, and it is an endogenous antagonist of XIAP, cIAP1, and cIAP2. In the last decade, small-molecule Smac mimetics have been developed to induce death receptor-mediated cell death activity. Several research groups have shown that Smac mimetics are capable of targeting multiple IAPs and increasing apoptosis in TRAIL-resistant breast cancer cell lines $[160,161]$. Combination of Smac mimetics with inhibitors of platelet-derived growth factor receptor (PDGFR), insulin-like growth factor 1 receptor (IGF1R) and epidermal growth factor receptor (EGFR) significantly increases apoptotic cell death compared to monotherapy in human glioblastoma cells [162], and combined therapy of Smac mimetics with inhibitors of FMS-like tyrosine kinase 3 (FLT3) and BCR-ABL resulted in similar effects against leukemia [163,164].

Thus, inhibition of both the extrinsic and intrinsic apoptotic pathways is implicated in chemoresistance in many cancer cells. This chemoresistance may be due to downregulation of cell surface death receptors and/or up-regulation of anti-apoptotic proteins such as Bcl-2 like, cFLIP, or IAPs, making the targeting of those molecules an attractive and important task in the development of the next generation cancer chemotherapies (Figure 1). 
Table 1. Cellular targets for the inhibition of anti-apoptotic mechanisms in cancer.

\begin{tabular}{|c|c|c|c|c|}
\hline \multicolumn{2}{|c|}{ Target Proteins } & Anti-Apoptotic Mechanisms & Inhibitors & Type of Tumor \\
\hline \multicolumn{2}{|c|}{ The cellular FLICE-like inhibitory protein (cFLIP) } & $\begin{array}{l}\text { Competitive interference with } \\
\text { caspase- } 8 \text { recruitment to DISC }\end{array}$ & $\begin{array}{c}\text { Cycloheximide [136] } \\
\text { miRNA-708 [165] } \\
\text { CXCR2 antagonist Z10397767 [142] } \\
\text { Thioridazine [143] } \\
\text { Histone deacetylase inhibitor LBH589 [144] } \\
\text { Withanolide E and analogues [145] }\end{array}$ & $\begin{array}{c}\text { murine thymoma EL-4 cells } \\
\text { renal cancer cells } \\
\text { prostate cancer cells } \\
\text { human head and neck cancer cells } \\
\text { pancreatic cancer cells } \\
\text { renal carcinoma }\end{array}$ \\
\hline \multirow{3}{*}{ Bcl-2-like proteins } & $\begin{array}{l}\text { Bcl-2 } \\
\text { Bcl-XL } \\
\text { Bcl-W }\end{array}$ & $\begin{array}{l}\text { Inhibition of pore-forming Bax/Bak } \\
\text { in mitochondria }\end{array}$ & Small-molecule ABT-263 (navitoclax) [147] & $\begin{array}{c}\text { human colorectal cancer } \\
\text { small cell lung cancer } \\
\text { leukemia } \\
\text { lymphoma } \\
\text { hematologic malignances }\end{array}$ \\
\hline & Mcl-1 & Antagonizes Bax and Bak activation & Small-molecule S63845 [149] & $\begin{array}{c}\text { myeloma } \\
\text { leukaemia } \\
\text { lymphoma }\end{array}$ \\
\hline & Bfl-1/A1 & Binds to BH3-only proteins [166] & 4-chloro-1-methyl-3-nitroquinolin-2-one [151] & $\begin{array}{l}\text { MEF and melanoma cell lines primed } \\
\text { with various A1 constructs }\end{array}$ \\
\hline \multirow{4}{*}{ IAPs } & & & AZD5582 [156] & pancreatic cancer \\
\hline & $\begin{array}{c}\text { BIRC4 } \\
\text { (X-linked IAP/XIAP/hILP) } \\
\text { BIRC2 } \\
\text { (cellular IAP1/cIAP1/HIAP2) } \\
\text { BIRC3 } \\
\text { (cellular IAP2/cIAP2/HIAP1) }\end{array}$ & $\begin{array}{c}\text { Prevent downstream proteolytic } \\
\text { processing of pro-caspase-3, }-6 \text { and } \\
-7[117,167]\end{array}$ & $\begin{array}{c}\text { Oligonucleotide } \\
\text { AEG-35156 [157] } \\
\text { Smac mimetics }[160-164,168] .\end{array}$ & $\begin{array}{c}\text { Panc-1 pancreatic carcinoma cells, xenograft } \\
\text { models of prostate, colon, and lung cancer, } \\
\text { lymphoma, melanoma, breast cancer, } \\
\text { breast cancer } \\
\text { multiple myeloma } \\
\text { human glioblastoma } \\
\text { non-small cell lung cancer } \\
\text { leukemia }\end{array}$ \\
\hline & & & Small-molecule AEG40730 [169] & HCT116 Cell Line human colon carcinoma \\
\hline & BIRC5 (Survivin) & $\begin{array}{l}\text { Binds to pro-caspase-9, preventing } \\
\text { its recruitment to Apaf1 [170] } \\
\text { Inhibits SMAC [171] }\end{array}$ & Small-molecule YM155 [159] & colorectal and lung adenocarcinoma \\
\hline $\begin{array}{l}\text { Serine/threonine } \\
\text { protein kinases }\end{array}$ & WEE1 & Dysregulates CDK1 and CDK2 & MK1775 (AZD 1775) & $\begin{array}{c}\text { ovarian cancer } \\
\text { advanced gastric adenocarcinoma } \\
\text { metastatic solid tumors [47] }\end{array}$ \\
\hline
\end{tabular}




\section{Transforming Growth Factors}

Transforming growth factor (TGF) is a signaling pathway for the family of cytokines that includes the polypeptide growth factors TGF- $\alpha$ and TGF- $\beta$. Depending on the number of polypeptide chains, they act through different receptor mechanisms in vitro and in vivo [172]. TGF- $\alpha$, a single chain polypeptide, stimulates epidermal growth factor by activating the epidermal growth factor receptor (EGFR), while the two chain polypeptide TGF- $\beta$ is associated with proliferation, differentiation, renewal of stem-like cell populations and invasion [173]. Furthermore, TGF- $\beta$ consists of both similarity to Mothers against decapentaplegic (SMAD)-dependent and independent pathways [174]. Although both growth factors are upregulated in many cancers, TGF- $\beta$ and its isomers (TGF- $\beta 1$, TGF- $\beta 2$, TGF- $\beta 3$ ) have been the most studied pathways in cancer treatment, possibly due to their dual action during cancer progression. It is well known that TGF- $\beta$ acts as tumor suppressor in healthy cells or at early stages of cancer development by inducing growth arrest and apoptosis, however it promotes cancer progression by initiating tumor cell migration and stimulating epithelial to mesenchymal transition (EMT) at later phases of cancer $[175,176]$. Recent studies have indicated EMT's association with TGF- $\beta$ induced cancer/tumor progression, chemoresistance and metastasis $[177,178]$. The mechanistic action for TGF- $\beta$ to drive drug resistance during chemotherapy appears to be its overactivation, promotion of EMT, regulation of DNA repair and initiation of cell cycle arrest and autophagy [177]. TGF- $\beta$ downregulation has been linked to overcoming doxorubicin resistance in HCT116 colon cancer cells [178] and is shown to exert oxaliplatin resistance in colorectal cancer [177], high resistance of breast cancer cells to doxorubicin through EMT overexpression [179] as well as resistance of triple negative breast cancer cells to paclitaxel [180].

Several combinatorial strategies are being employed aimed at overcoming chemoresistance of cancer cells during chemotherapy involving TGF- $\beta$ inhibition. A number of ALK5 inhibitors such as EW-7195, EW-7203 and IN-1130 have shown to effectively block TGF- $\beta 1$-induced SMAD signaling, EMT and breast cancer metastasis in vivo [181-183], demonstrating the potential of these small molecules to prevent breast cancer metastasis to the lung. Another TGF- $\beta$ type I receptor kinase inhibitor LY2157299 also blocked paclitaxel-induced IL-8 transcription and cancer stem-like cell expansion in vivo during triple negative breast cancer treatment using mouse xenograft models [180]. Furthermore, combined therapy with sorafenib (tyrosine kinase inhibitor) and galunisertib resulted in elevated apoptosis and low proliferation level in hepatocellular carcinoma slices [184] while TßRI inhibitor LY364947 and erlotinib treatment led to decreased motility rate of NSLCL cells [175].

\section{Role of Cell Adhesion Molecules (CAMs) in Chemoresistance}

A growing body of evidence indicates that cell-cell and cell-extracellular matrix (ECM) contacts can modulate drug resistance and the phenomenon is referred to as cell adhesion-mediated drug resistance (CAM-DR) [185,186]. Most mechanisms of CAM-DR are not fully understood, possibly due to multifactorial processes involving different molecular players such as cell adhesion molecules and ECM components. The literature indicates that multidrug-resistant phenotypes of cancer cells are associated with cell adhesion molecules that play a key role in cell adhesion processes [186]. An increasing number of studies demonstrate that different types of CAMs may be involved in the resistance to chemotherapy treatment $[16,185,187-190]$. This section discusses the literature focusing on CAMs as attractive therapeutic targets to overcome chemoresistance in cancer therapy.

The broad spectrum of CAMs is classified into different families, although most belong to four principal classes: Ig (immunoglobulin) superfamily (IgSF CAMs), integrins, cadherins and selectins. Some unclassified CAMs including CD 44 and epithelial cell adhesion molecule (EpCAM), are considered as separate to the above four classifications [191-193]. Over the past decade, a number of studies have demonstrated that many CAMs are overexpressed in chemotherapy-resistant cancer cells, whereas some CAMs, such as integrin $\alpha 2 \beta 1, C D 31$ and E-cadherin under expressed in cancer cells $[16,194]$. The loss of E-cadherin expression is related to chemoresistance in response to paclitaxel and docetaxel in prostate cancer [195]. It was shown that EMT reduces E-cadherin expression via 
EMT inducers [196]. EMT leads to docetaxel resistance in prostate cancer and decreases E-cadherin expression associated with disease relapse [197].

Numerous studies have demonstrated that cell-adhesion mediated drug resistance (CAM-DR) is based on a number of mechanisms. For example, protecting cells from drug-induced cytotoxic damage in cancer cells with CAM-DR was achieved by enhancing the repair of DNA damage due to overexpression of histone methyltransferase multiple myeloma SET domain (MMSET) in multiple myeloma [198,199], or elevated expression of FANCF and RAD51C which are important DNA repair proteins [187,200-204]. Another mechanisms of CAM-DR is increasing resistance to detachment-induced cell death (anoikis resistance), and inhibition of FAS-mediated apoptosis [205-208].

Despite these findings, the mechanisms involved in cell-adhesion mediated drug resistance are not fully explored. Accumulating evidence points to a critical role of post-transcriptional processes and the epigenetic modifications that can induce drug resistance [199].

There are some attractive features of anti CAM-DR strategy. Thus, studies mentioned above have revealed that abnormal expression of cell adhesion molecules is frequently associated with aggressive tumor growth, metastasis and resistance to chemotherapy [209]. Moreover, modification and/or disruption of E-cadherin was detected at early stages of tumor development [210-212] and also CD44 is involved in an early step necessary for metastasis [213]. It can be assumed that regulation of CAMs can prevent the development of acquired mechanisms of drug resistance.

These findings indicate that cell adhesion molecules may serve as a target for personalized cancer therapy due to their frequent expression in different types of neoplasms, specific distribution in normal cells and dysregulated before the invasion [186]. Moreover, new molecular insight such as whole genome sequencing reveals that frequent somatic mutations in gastric cancers [214], lung squamous cell carcinoma [215] and leukemia [216] were in cell adhesion genes. Therefore, targeting CAMs introduces special interest for scientists and pharmacological companies as well as for the development of anti-CAM-DR strategy to sensitize cancer cells to therapeutic drugs $[186,217]$.

Most research targeting CAM-DR has focused largely on integrins [202,218-241] (see Table 2). Considerable efforts have been directed at examining the inhibitory action of integrin agonists, such as antibodies, peptides and small molecules $[218,229,230]$. Different preclinical in vitro and in vivo studies showed that targeting $\alpha 4$ integrin by antibodies sensitizes multiple myeloma to chemotherapy using melphalan or bortezomib $[223,237]$ (Table 2), and $\alpha 4$ integrin small molecule inhibitor TBC3486 increases acute lymphoblastic leukemia sensitivity to vincristine treatment [221,222]. There is only one known Phase I/II clinical trial (NCT00675428) in patients with refractory multiple myeloma treated by natalizumab, a recombinant humanized IgG4 monoclonal antibody, which binds integrin $\alpha 4$. However, this clinical trial was terminated due to low enrollment.

The synthetic Arg-Gly-Asp-motif peptide integrin $\alpha 5 \alpha 3$ inhibitor EMD-121974 (cilengitide), was a very attractive drug for anti-CAM-DR strategy as it was shown to demonstrate a positive outcome in preclinical studies [236]. Cilengitide was tested in several clinical trials for different types of tumors, including glioma, NSCLC and squamous cell carcinoma [231-235]. Despite positive results from preclinical studies and second phase clinical trials, the addition of cilengitide to temozolomide chemo and radiotherapy did not improve patient's overall survival with newly diagnosed glioblastoma in an EORTC Phase III randomized, controlled, multicenter clinical trial [232]. ExCentric, a multicentre open-label Phase II trial, showed that cilengitide did not enhance survival of MGMT-promoter unmethylated glioblastoma when used in combination with procarbazine and metronomic temozolomide compared with historical data [235]. Results of the randomized Phase I/II ADVANTAGE trial (Phase II part) demonstrated that cilengitide with cetuximab and platinum-based chemotherapy in recurrent/metastatic squamous cell carcinoma of the head and neck did not result in any positive outcome [234]. Cilengitide combined with cetuximab and platinum-based chemotherapy was tested in an open-label randomized controlled Phase II study (CERTO) as first-line treatment for patients with advanced non-small-cell lung cancer (NSCLC) [233]. The study showed that patients with advanced NSCLC had improved progression-free survival rate compared with control. 
It was shown that the 3-hydroxy-3-methylglutaryl-coenzyme (HMG-CoA) reductase inhibitor simvastatin can selectively inhibit integrins, shows antimyeloma activity and up-regulates HMG-CoA reductase in chemotherapy-resistant cancer cells [238-240]. Schmidmaier and co-authors showed that simvastatin at very low concentrations overcomes CAM-DR in multiple myeloma by geranylgeranylation of Rho proteins and activation of Rho kinase [228]. In addition, simvastatin diminishes tumor cell adhesion to human peritoneal mesothelial cells by reduced expression of VCAM-1 and $\beta 1$ integrin [241]. Simvastatin as an inhibitor of CAM-DR in patients with refractory multiple myeloma was tested in Phase II clinical trials by Ludwig-Maximilian University of Munich. This clinical trial demonstrated suppression of drug resistance by inhibition of HMG-CoA-reductase [17].

Although most studies in this area have focused on integrins, other CAMs have potential for anti-CAM-DR strategy. Thus, recent data showed that down-regulation of endothelial adhesion receptor CD31/PECAM-1 (platelet endothelial cell adhesion molecule-1) was associated with resistance against oxidative stress and DNA damage in angiosarcoma cells due to YAP (yes-associated protein) signaling, and inhibition of YAP by pazopanib re-sensitized cancer cells to doxorubicin [242]. Pazopanib may find use as a CAM-DR inhibitor as it inhibits VEGF-induced up-regulation of adhesion molecules on tumor cells [243]. Pazopanib maintenance therapy provided a statistically significant and clinically meaningful progression-free survival (PFS) benefit in patients with advanced epithelial ovarian, fallopian tube, or primary peritoneal cancers in Phase III trials [244].

The intercellular adhesion molecule E-cadherin is considered as a key player in the process of acquiring chemoresistance $[188,195,210,212,245]$. Down regulation of E-cadherin has been noted in many human cancers [210], and is associated with chemoresistance in prostate cancer cells (PCa) [195]. Overexpression of E-cadherin in chemoresistant PCa cells inhibited cell migration and invasion and increased their sensitivity to paclitaxel [195]. In addition, docetaxel treatment can lead to E-cadherin down regulation leading to poor prognosis in prostate cancer [245]. It is suggested that docetaxel treatment leads to a clonal selection of highly invasive prostate cancer cells thus leading to chemosresistance [245]. This chemoresistance may be due, at least in part, to the acquisition of a mesenchymal and stem cell-like phenotype. These data suggest the development of drugs allowing E-cadherin re-expression may have novel therapeutic possibilities.

Recently, it was shown that growth promoting Notch signaling has a role in E-cadherin associated cancer chemoresistance [195], and Notch pathway up-regulation has been observed in PCa clinical samples [246]. An inverse correlation between E-cadherin and Notch-1 expression was seen in chemoresistant PCa cells, and treatment of these cells with a $\gamma$-secretase inhibitor (GSI) restored chemosensitvity to paclitaxel [195]. The $\gamma$-secretase activity is required for the final cleavage step of the precursor form of Notch to activate Notch signaling [247]. Inhibiting Notch signaling may also be of benefit in other cancer types, as the GSI MK-0752 combined with docetaxel improved the health of patients with advanced breast cancer in Phase II clinical trials [248]. These initial results of preclinical studies suggest inhibitors of Notch signaling as potential anti CAM-DR drugs and further studies are warranted.

There is increasing evidence that selectins play an important role in the progression of different types of cancer, in particular the interaction of tumor cells with the endothelium that is needed for extravasation and the formation of new metastatic lesions $[249,250]$ Selectins are molecules expressed on the cell surface of endothelial cells that have been shown to promote the first interaction between an extravasating cell and the blood-vessel wall [251], and have been implicated in CAM-DR [252-255]. As metastasis can be dramatically reduced in mice deficient for P- and L-selectins, this suggests selectins as possible drug targets for chemosensitization [256], and it has been reported that small molecule glycomimetic selectin antagonists have the ability to sensitize cancer cells [252-255]. For example, the small molecule pan-selectin inhibitor GMI-1070 enhances the sensitization of multiple myeloma cells to bortezomib, both in vitro and in vivo, by targeting P-selectins [252]. Similar effects were seen when P-selectins were blocked using monoclonal antibodies [254], and the addition of E-selectin inhibitor 
GMI-1271 to induction chemotherapy in elderly patients with untreated acute myeloid leukemia demonstrated a high remission rate and low mortality [255,257]. In addition, pulmonary metastasis of melanoma cells was shown to be reduced in vivo using the P-selectin ligand antagonist holothurian glycosaminoglycan [253]. These recent studies provide support that targeting the selectins may be a good strategy for chemosensitization.

CD44, a transmembrane receptor for hyaluronan, is a functional component of cell adhesion-mediated drug resistance, as its blockade was shown to sensitize drug resistant multiple myeloma to lenalidomide [258,259]. In addition, Zheng et al. recently reported that small molecule aurora kinase inhibitors attenuated breast tumor-initiating cells and overcame epirubicin resistance by CD44 inhibition [260]. These data suggest that CD44 should be evaluated as a putative biomarker of sensitivity to various chemotherapeutic drugs.

These data strongly support that translation of CAM-DR signaling pathway regulators to clinic in combination with standard therapy can be considered as a rational strategy to overcome resistance. However, in comparison with the significant advances in other strategies for overcoming chemoresistance, progress made with respect to anti CAM-DR therapy has been relatively slow. A major therapy failure was a Phase III clinical trial using cilengitide in newly diagnosed glioblastoma [232]. Despite the challenges in this area and gaps in our knowledge, our understanding is that the development of effective strategies for overcoming chemoresistance will require a better understanding of cell adhesion drug resistance and its interaction with other types of chemoresistance. Table 2 summarizes CAM signaling pathways involved in chemoresistance. 
Table 2. Regulation of drug resistance related to cell adhesion molecules.

\begin{tabular}{|c|c|c|c|c|c|}
\hline Type of CAM & Type of Tumor & Chemotherapy Drugs & Signaling Pathway & $\begin{array}{c}\text { Preclinical Anti CAM-DR } \\
\text { Treatment }\end{array}$ & Clinical \\
\hline \multirow{2}{*}{ Integrin $\alpha 4$} & acute lymphoblastic leukemia & vincristine & Direct inhibition & $\begin{array}{l}\text { Integrin } \alpha 4 \text { inhibitor small } \\
\text { molecule TBC3486 [221,222] }\end{array}$ & - \\
\hline & multiple myeloma & melphalan & Direct inhibition & $\begin{array}{l}\text { Anti-integrin } \alpha 4 \\
\text { antibody [223] }\end{array}$ & - \\
\hline Integrin $\alpha 4$ & multiple myeloma & bortezomib & Direct inhibition & $\begin{array}{l}\text { inhibitor Natalizumab, a } \\
\text { recombinant humanized IgG4 } \\
\text { monoclonal antibody, which binds } \\
\text { integrin } \alpha 4 \text { [237] }\end{array}$ & $\begin{array}{l}\text { Natalizumab—Phase I/II } \\
\text { (NCT00675428)—multiple myeloma } \\
\text { (terminated) }\end{array}$ \\
\hline \multirow{3}{*}{ Integrin $\alpha 4$} & \multirow{3}{*}{ Glioma cells } & \multirow{3}{*}{ temozolomide } & \multirow{3}{*}{ Direct inhibition } & \multirow{3}{*}{$\begin{array}{l}\text { EMD-121974 (Cilengitide), a } \\
\text { synthetic Arg-Gly-Asp-motif } \\
\text { peptide- } \alpha 4 \text { integrin inhibitor [224] }\end{array}$} & $\begin{array}{l}\text { Cilengitide with temozolomide_-Phase III } \\
\text { (NCT00689221)—newly diagnosed } \\
\text { glioblastoma [232] }\end{array}$ \\
\hline & & & & & $\begin{array}{l}\text { Cilengitide combined with cetuximab and } \\
\text { platinum-based chemotherapy } \\
\text { (NCT00842712)—Phase II-non-small-cell } \\
\text { lung cancer [233] } \\
\text { Cilengitide with Cisplatin, 5-fluorouracil, } \\
\text { and cetuximab (NCT00705016)-Phase } \\
\text { I/II-squamous cell carcinoma of the head } \\
\text { and neck [234] }\end{array}$ \\
\hline & & & & & $\begin{array}{l}\text { Cilengitide with metronomic temozolomide, } \\
\text { procarbazine, and standard radiotherapy } \\
\text { (NCT01124240)-Phase II [235] }\end{array}$ \\
\hline Integrin $\alpha 5 \beta 1$ & squamous cell carcinoma & cisplatin & Direct inhibition & $\begin{array}{l}\text { Anti- } \alpha 5 \beta 1 \text { Integrin Neutral } \\
\text { Antibody [225] }\end{array}$ & - \\
\hline $\begin{array}{l}\text { VLA-4 (integrin } \alpha 4 \beta 1 \text { ) and } \\
\text { VLA-5 (integrin } \alpha 5 \beta 1 \text { ) }\end{array}$ & myeloma & $\begin{array}{l}\text { doxorubicin and } \\
\text { melphalan }\end{array}$ & Direct inhibition & Anti-VLA-4 VLA-5 antibody [226] & - \\
\hline $\begin{array}{l}\text { VLA-4 (integrin } \alpha 4 \beta 1 \text { ) and } \\
\text { LFA- } 1 \text { (integrin } \alpha \mathrm{L} \beta 2 \text { ) }\end{array}$ & multiple myeloma & $\begin{array}{l}\text { melphalan, treosulfan, } \\
\text { doxorubicin, } \\
\text { dexamethasone, and } \\
\text { bortezomib }\end{array}$ & $\begin{array}{l}\text { HMG-CoA/GG-PP/ } \\
\text { Rho/Rho-kinase }\end{array}$ & $\begin{array}{l}\text { Anti LFA-1 and VLA-4 antibodies. } \\
\text { Geranylgeranyl transferase } \\
\text { (GGTase) inhibitor GGTI-298 and } \\
\text { Rho kinase specific inhibitors } \\
\text { Y-27632. } \\
\text { The HMG-CoA reductase inhibitor } \\
\text { simvastatin [238-240]. }\end{array}$ & $\begin{array}{l}\text { Simvastatin with bortezomib, bendamustin } \\
\text { dexamethasone-Phase II (NCT00399867) } \\
{[227,228] \text {-in Patients with Refractory }} \\
\text { Multiple Myeloma [17] }\end{array}$ \\
\hline CD31/PECAM-1 & Angiosarcoma & Doxorubicin & YAP & $\begin{array}{l}\text { YAP inhibitors } \\
\text { (Pazopanib) [242] }\end{array}$ & $\begin{array}{l}\text { Pazopanib_Phase III NCT00866697- } \\
\text { Ovarian, Fallopian Tube or Primary } \\
\text { Peritoneal Adenocarcinoma [244] }\end{array}$ \\
\hline
\end{tabular}


Table 2. Cont.

\begin{tabular}{|c|c|c|c|c|c|}
\hline Type of CAM & Type of Tumor & Chemotherapy Drugs & Signaling Pathway & $\begin{array}{c}\text { Preclinical Anti CAM-DR } \\
\text { Treatment }\end{array}$ & Clinical \\
\hline E-cadherin & Prostate cancer & Paclitaxel & Notch & $\begin{array}{l}\text { The } \gamma \text {-secretase inhibitor } \\
\text { (GSI, a Notch inhibitor) [195] }\end{array}$ & $\begin{array}{l}\text { The } \gamma \text {-secretase inhibitor MK-0752-Phase } \\
\text { II-NCT00645333 } \\
\text { Breast cancer }\end{array}$ \\
\hline PSGL-1/P-selectin & $\begin{array}{c}\text { In macrophage for } \\
\text { macrophage-mediated } \\
\text { myeloma drug resistance }\end{array}$ & Bortezomib & Direct inhibition & $\begin{array}{l}\text { The pan-selectin inhibitor } \\
\text { GMI-1070 [252] }\end{array}$ & - \\
\hline \multirow{2}{*}{ P-selectin } & Melanoma & - & Direct inhibition & $\begin{array}{l}\text { P-selectin inhibitor- Holothurian } \\
\text { glycosaminoglycan [253] }\end{array}$ & - \\
\hline & Multiple myeloma & Bortezomib & Direct inhibition & $\begin{array}{l}\text { Humanized Monoclonal } \\
\text { Antibodies [254] }\end{array}$ & - \\
\hline E-selectin & Multiple myeloma & Bortezomib & Direct inhibition & $\begin{array}{l}\text { E-selectin inhibitor } \\
\text { GMI-1271 [255] }\end{array}$ & $\begin{array}{l}\text { E-selectin inhibitor GMI-1271-with } \\
\text { mitoxantrone, etoposide and cytarabine } \\
\text { Phase I/II NCT02306291-acute myeloid } \\
\text { leukemia [257] }\end{array}$ \\
\hline $\mathrm{CD} 44$ & Breast cancer & epirubicin & Aurora kinase & $\begin{array}{l}\text { Aurora kinase inhibitor } \\
\text { AKI603 [260] }\end{array}$ & - \\
\hline
\end{tabular}




\section{Conclusions}

Cancer cells can escape the toxic effects of chemotherapy through a variety of mechanisms such as cell cycle, apoptosis and cell adhesion. Studies reveal that the mechanisms by which cancer cells mediate chemoresistance can involve various oncogenic factors and several different signaling pathways. However, these mechanisms can be targeted using specific inhibitors that may improve the sensitivity of cancer cells to chemotherapeutic agents when used in combination. Studies highlighted in this review provide evidence that specific inhibitors of components in key signaling pathways involved in chemoresistance may indeed improve overall cancer therapy. With a more personalized medical approach to cancer envisioned for the future, an in-depth knowledge of chemoresistance mechanisms in specific cancer types together with proper diagnosis is required; this will hopefully lead to a more targeted and informed cancer treatment, and prove a useful strategy to overcome drug treatment failures that ultimately lead to recurrence and death.

Acknowledgments: This work was supported by Grant No. 144-2018/010-2018 from Nazarbayev University. The funders played no role in the design or execution of this work, nor in the writing of this paper.

Conflicts of Interest: The authors declare no conflict of interest.

\section{References}

1. Kelland, L. The resurgence of platinum-based cancer chemotherapy. Nat. Rev. Cancer 2007, 7, 573-584. [CrossRef] [PubMed]

2. Socinski, M.A. Cytotoxic chemotherapy in advanced non-small cell lung cancer: A review of standard treatment paradigms. Clin. Cancer Res. 2004, 10, 4210s-4214s. [CrossRef] [PubMed]

3. Bartkova, J.; Rezaei, N.; Liontos, M.; Karakaidos, P.; Kletsas, D.; Issaeva, N.; Vassiliou, L.V.; Kolettas, E.; Niforou, K.; Zoumpourlis, V.C.; et al. Oncogene-induced senescence is part of the tumorigenesis barrier imposed by DNA damage checkpoints. Nature 2006, 444, 633-637. [CrossRef] [PubMed]

4. Ciccia, A.; Elledge, S.J. The DNA damage response: Making it safe to play with knives. Mol. Cell 2010, 40, 179-204. [CrossRef] [PubMed]

5. Jackson, S.P.; Bartek, J. The DNA-damage response in human biology and disease. Nature 2009, 461, 1071-1078. [CrossRef] [PubMed]

6. Grossi, V.; Peserico, A.; Tezil, T.; Simone, C. p38 $\alpha$ MAPK pathway: A key factor in colorectal cancer therapy and chemoresistance. World J. Gastroenterol. 2014, 20, 9744-9758. [CrossRef] [PubMed]

7. Dominguez-Brauer, C.; Thu, K.L.; Mason, J.M.; Blaser, H.; Bray, M.R.; Mak, T.W. Targeting Mitosis in Cancer: Emerging Strategies. Mol. Cell 2015, 60, 524-536. [CrossRef] [PubMed]

8. Cicenas, J.; Kalyan, K.; Sorokinas, A.; Jatulyte, A.; Valiunas, D.; Kaupinis, A.; Valius, M. Highlights of the Latest Advances in Research on CDK Inhibitors. Cancers 2014, 6, 2224-2242. [CrossRef] [PubMed]

9. Yim, H. Current clinical trials with polo-like kinase 1 inhibitors in solid tumors. Anticancer Drugs 2013, 24, 999-1006. [CrossRef] [PubMed]

10. Kerr, J.F.; Wyllie, A.H.; Currie, A.R. Apoptosis: A basic biological phenomenon with wide-ranging implications in tissue kinetics. Br. J. Cancer 1972, 26, 239-257. [CrossRef] [PubMed]

11. Ubah, O.C.; Wallace, H.M. Cancer therapy: Targeting mitochondria and other sub-cellular organelles. Curr. Pharm. Des. 2014, 20, 201-222. [CrossRef] [PubMed]

12. Wong, R.S.Y. Apoptosis in cancer: From pathogenesis to treatment. J. Exp. Clin. Cancer Res. 2011, $30,87$. [CrossRef] [PubMed]

13. Moh, M.C.; Shen, S. The roles of cell adhesion molecules in tumor suppression and cell migration: A new paradox. Cell Adhes. Migr. 2009, 3, 334-336. [CrossRef]

14. Albelda, S.M.; Buck, C.A. Integrins and other cell adhesion molecules. FASEB J. 1990, 4, 2868-2880. [CrossRef] [PubMed]

15. Cohen, M.B.; Griebling, T.L.; Ahaghotu, C.A.; Rokhlin, O.W.; Ross, J.S. Cellular adhesion molecules in urologic malignancies. Am. J. Clin. Pathol. 1997, 107, 56-63. [CrossRef] [PubMed]

16. Schmidmaier, R.; Baumann, P. ANTI-ADHESION evolves to a promising therapeutic concept in oncology. Curr. Med. Chem. 2008, 15, 978-990. [CrossRef] [PubMed] 
17. Schmidmaier, R.; Baumann, P.; Bumeder, I.; Meinhardt, G.; Straka, C.; Emmerich, B. First clinical experience with simvastatin to overcome drug resistance in refractory multiple myeloma. Eur. J. Haematol. 2007, 79, 240-243. [CrossRef] [PubMed]

18. Durand, R.E.; Sutherland, R.M. Effects of intercellular contact on repair of radiation damage. Exp. Cell Res. 1972, 71, 75-80. [CrossRef]

19. Sherr, C.J.; Roberts, J.M. CDK inhibitors: Positive and negative regulators of G1-phase progression. Genes Dev. 1999, 13, 1501-1512. [CrossRef] [PubMed]

20. Canavese, M.; Santo, L.; Raje, N. Cyclin dependent kinases in cancer. Cancer Biol. Ther. 2012, 13, $451-457$. [CrossRef] [PubMed]

21. Bagella, L.; Sun, A.; Tonini, T.; Abbadessa, G.; Cottone, G.; Paggi, M.G.; De Luca, A.; Claudio, P.P.; Giordano, A. A small molecule based on the pRb2/p130 spacer domain leads to inhibition of cdk2 activity, cell cycle arrest and tumor growth reduction in vivo. Oncogene 2007, 26, 1829-1839. [CrossRef] [PubMed]

22. Schwartz, G.K. CDK inhibitors: Cell cycle arrest versus apoptosis. Cell Cycle 2002, 1, 122-123. [CrossRef] [PubMed]

23. Cirillo, D.; Pentimalli, F.; Giordano, A. Peptides or small molecules? Different approaches to develop more effective CDK inhibitors. Curr. Med. Chem. 2011, 18, 2854-2866. [CrossRef] [PubMed]

24. Kim, E.H.; Kim, S.U.; Shin, D.Y.; Choi, K.S. Roscovitine sensitizes glioma cells to TRAIL-mediated apoptosis by downregulation of survivin and XIAP. Oncogene 2004, 23, 446-456. [CrossRef] [PubMed]

25. Lubanska, D.; Porter, L. Revisiting CDK Inhibitors for Treatment of Glioblastoma Multiforme. Drugs $R D$ 2017, 17, 255-263. [CrossRef] [PubMed]

26. Bose, P.; Simmons, G.L.; Grant, S. Cyclin-dependent kinase inhibitor therapy for hematologic malignancies. Expert Opin. Investig. Drugs 2013, 22, 723-738. [CrossRef] [PubMed]

27. Hayashi, T.; Adachi, K.; Ohba, S.; Hirose, Y. The Cdk inhibitor flavopiridol enhances temozolomide-induced cytotoxicity in human glioma cells. J. Neurooncol. 2013, 115, 169-178. [CrossRef] [PubMed]

28. Haider, C.; Grubinger, M.; Reznickova, E.; Weiss, T.S.; Rotheneder, H.; Miklos, W.; Berger, W.; Jorda, R.; Zatloukal, M.; Gucky, T.; et al. Novel inhibitors of cyclin-dependent kinases combat hepatocellular carcinoma without inducing chemoresistance. Mol. Cancer Ther. 2013, 12, 1947-1957. [CrossRef] [PubMed]

29. Yang, L.; Zhou, Y.; Li, Y.; Zhou, J.; Wu, Y.; Cui, Y.; Yang, G.; Hong, Y. Mutations of p53 and KRAS activate NF-kappaB to promote chemoresistance and tumorigenesis via dysregulation of cell cycle and suppression of apoptosis in lung cancer cells. Cancer Lett. 2015, 357, 520-526. [CrossRef] [PubMed]

30. Woo, M.G.; Xue, K.; Liu, J.; McBride, H.; Tsang, B.K. Calpain-mediated processing of p53-associated parkin-like cytoplasmic protein (PARC) affects chemosensitivity of human ovarian cancer cells by promoting p53 subcellular trafficking. J. Biol. Chem. 2012, 287, 3963-3975. [CrossRef] [PubMed]

31. Mirzayans, R.; Andrais, B.; Scott, A.; Murray, D. New insights into p53 signaling and cancer cell response to DNA damage: Implications for cancer therapy. J. Biomed. Biotechnol. 2012, 2012, 170325. [CrossRef] [PubMed]

32. Zhao, H.; Piwnica-Worms, H. ATR-mediated checkpoint pathways regulate phosphorylation and activation of human Chk1. Mol. Cell. Biol. 2001, 21, 4129-4139. [CrossRef] [PubMed]

33. Zhao, H.; Watkins, J.L.; Piwnica-Worms, H. Disruption of the checkpoint kinase 1/cell division cycle 25A pathway abrogates ionizing radiation-induced S and G2 checkpoints. Proc. Natl. Acad. Sci. USA 2002, 99, 14795-14800. [CrossRef] [PubMed]

34. He, C.; Li, L.; Guan, X.; Xiong, L.; Miao, X. Mutant p53 Gain of Function and Chemoresistance: The Role of Mutant p53 in Response to Clinical Chemotherapy. Chemotherapy 2017, 62, 43-53. [CrossRef] [PubMed]

35. Lehmann, B.D.; Pietenpol, J.A. Targeting mutant p53 in human tumors. J. Clin. Oncol. 2012, 30, 3648-3650. [CrossRef] [PubMed]

36. Fan, S.; Smith, M.L.; Rivet, D.J., 2nd; Duba, D.; Zhan, Q.; Kohn, K.W.; Fornace, A.J., Jr.; O'Connor, P.M. Disruption of p53 function sensitizes breast cancer MCF-7 cells to cisplatin and pentoxifylline. Cancer Res. 1995, 55, 1649-1654. [PubMed]

37. Maréchal, A.; Zou, L. DNA Damage Sensing by the ATM and ATR Kinases. Cold Spring Harb. Perspect. Biol. 2013, 5, a012716. [CrossRef] [PubMed]

38. Chin, K.V.; Ueda, K.; Pastan, I.; Gottesman, M.M. Modulation of activity of the promoter of the human MDR1 gene by Ras and p53. Science 1992, 255, 459-462. [CrossRef] [PubMed] 
39. Ma, C.X.; Janetka, J.W.; Piwnica-Worms, H. Death by releasing the breaks: CHK1 inhibitors as cancer therapeutics. Trends Mol. Med. 2011, 17, 88-96. [CrossRef] [PubMed]

40. Visconti, R.; Della Monica, R.; Grieco, D. Cell cycle checkpoint in cancer: A therapeutically targetable double-edged sword. J. Exp. Clin. Cancer Res. 2016, 35, 153. [CrossRef] [PubMed]

41. Dixon, H.; Norbury, C.J. Therapeutic exploitation of checkpoint defects in cancer cells lacking p53 function. Cell Cycle 2002, 1, 362-368. [CrossRef] [PubMed]

42. Iwata, T.; Uchino, T.; Koyama, A.; Johmura, Y.; Koyama, K.; Saito, T.; Ishiguro, S.; Arikawa, T.; Komatsu, S.; Miyachi, M.; et al. The G2 checkpoint inhibitor CBP-93872 increases the sensitivity of colorectal and pancreatic cancer cells to chemotherapy. PLoS ONE 2017, 12, e0178221. [CrossRef] [PubMed]

43. Harada, N.; Watanabe, Y.; Yoshimura, Y.; Sakumoto, H.; Makishima, F.; Tsuchiya, M.; Nakanishi, K.; Nakanishi, M.; Aoki, Y. Identification of a checkpoint modulator with synthetic lethality to p53 mutants. Anticancer Drugs 2011, 22, 986-994. [CrossRef] [PubMed]

44. Hirokawa, T.; Shiotani, B.; Shimada, M.; Murata, K.; Johmura, Y.; Haruta, M.; Tahara, H.; Takeyama, H.; Nakanishi, M. CBP-93872 inhibits NBS1-mediated ATR activation, abrogating maintenance of the DNA double-strand break-specific G2 checkpoint. Cancer Res. 2014, 74, 3880-3889. [CrossRef] [PubMed]

45. Blandino, G.; Di Agostino, S. New therapeutic strategies to treat human cancers expressing mutant p53 proteins. J. Exp. Clin. Cancer Res. 2018, 37, 30. [CrossRef] [PubMed]

46. Hirai, H.; Iwasawa, Y.; Okada, M.; Arai, T.; Nishibata, T.; Kobayashi, M.; Kimura, T.; Kaneko, N.; Ohtani, J.; Yamanaka, K.; et al. Small-molecule inhibition of Wee1 kinase by MK-1775 selectively sensitizes p53-deficient tumor cells to DNA-damaging agents. Mol. Cancer Ther. 2009, 8, 2992-3000. [CrossRef] [PubMed]

47. U.S. National Library of Medicine. Clinical Trials. 2018. Available online: https://clinicaltrials.gov/ct2/ show / NCT01357161 (accessed on 31 May 2018).

48. Duffy, M.J.; Synnott, N.C.; Crown, J. Mutant p53 as a target for cancer treatment. Eur. J. Cancer 2017, 83, 258-265. [CrossRef] [PubMed]

49. Haupt, S.; Raghu, D.; Haupt, Y. Mutant p53 Drives Cancer by Subverting Multiple Tumor Suppression Pathways. Front. Oncol. 2016, 6, 12. [CrossRef] [PubMed]

50. Willis, A.; Jung, E.J.; Wakefield, T.; Chen, X. Mutant p53 exerts a dominant negative effect by preventing wild-type p53 from binding to the promoter of its target genes. Oncogene 2004, 23, 2330-2338. [CrossRef] [PubMed]

51. Vijayakumaran, R.; Tan, K.H.; Miranda, P.J.; Haupt, S.; Haupt, Y. Regulation of Mutant p53 Protein Expression. Front. Oncol. 2015, 5, 284. [CrossRef] [PubMed]

52. Xue, W.; Zender, L.; Miething, C.; Dickins, R.A.; Hernando, E.; Krizhanovsky, V.; Cordon-Cardo, C.; Lowe, S.W. Senescence and tumour clearance is triggered by p53 restoration in murine liver carcinomas. Nature 2007, 445, 656-660. [CrossRef] [PubMed]

53. Muller, P.A.; Vousden, K.H. p53 mutations in cancer. Nat. Cell Biol. 2013, 15, 2-8. [CrossRef] [PubMed]

54. Parrales, A.; Ranjan, A.; Iyer, S.V.; Padhye, S.; Weir, S.J.; Roy, A.; Iwakuma, T. DNAJA1 controls the fate of misfolded mutant p53 through the mevalonate pathway. Nat. Cell Biol. 2016, 18, 1233-1243. [CrossRef] [PubMed]

55. Nordstrom, T.; Clements, M.; Karlsson, R.; Adolfsson, J.; Gronberg, H. The risk of prostate cancer for men on aspirin, statin or antidiabetic medications. Eur. J. Cancer 2015, 51, 725-733. [CrossRef] [PubMed]

56. Wang, Y.; Suh, Y.A.; Fuller, M.Y.; Jackson, J.G.; Xiong, S.; Terzian, T.; Quintas-Cardama, A.; Bankson, J.A.; El-Naggar, A.K.; Lozano, G. Restoring expression of wild-type p53 suppresses tumor growth but does not cause tumor regression in mice with a p53 missense mutation. J. Clin. Investig. 2011, 121, 893-904. [CrossRef] [PubMed]

57. Wang, T.; Lee, K.; Rehman, A.; Daoud, S.S. PRIMA-1 induces apoptosis by inhibiting JNK signaling but promoting the activation of Bax. Biochem. Biophys. Res. Commun. 2007, 352, 203-212. [CrossRef] [PubMed]

58. Lambert, J.M.; Moshfegh, A.; Hainaut, P.; Wiman, K.G.; Bykov, V.J. Mutant p53 reactivation by PRIMA-1MET induces multiple signaling pathways converging on apoptosis. Oncogene 2010, 29, 1329-1338. [CrossRef] [PubMed]

59. Zandi, R.; Selivanova, G.; Christensen, C.L.; Gerds, T.A.; Willumsen, B.M.; Poulsen, H.S. PRIMA-1Met/APR-246 induces apoptosis and tumor growth delay in small cell lung cancer expressing mutant p53. Clin. Cancer Res. 2011, 17, 2830-2841. [CrossRef] [PubMed] 
60. Saha, M.N.; Jiang, H.; Yang, Y.; Reece, D.; Chang, H. PRIMA-1Met/APR-246 displays high antitumor activity in multiple myeloma by induction of p73 and Noxa. Mol. Cancer Ther. 2013, 12, 2331-2341. [CrossRef] [PubMed]

61. Liang, Y.; Besch-Williford, C.; Hyder, S.M. PRIMA-1 inhibits growth of breast cancer cells by re-activating mutant p53 protein. Int. J. Oncol. 2009, 35, 1015-1023. [PubMed]

62. Walerych, D.; Lisek, K.; Sommaggio, R.; Piazza, S.; Ciani, Y.; Dalla, E.; Rajkowska, K.; Gaweda-Walerych, K.; Ingallina, E.; Tonelli, C.; et al. Proteasome machinery is instrumental in a common gain-of-function program of the p53 missense mutants in cancer. Nat. Cell Biol. 2016, 18, 897-909. [CrossRef] [PubMed]

63. Garufi, A.; Pistritto, G.; Cirone, M.; D'Orazi, G. Reactivation of mutant p53 by capsaicin, the major constituent of peppers. J. Exp. Clin. Cancer Res. 2016, 35, 136. [CrossRef] [PubMed]

64. Cordani, M.; Oppici, E.; Dando, I.; Butturini, E.; Dalla Pozza, E.; Nadal-Serrano, M.; Oliver, J.; Roca, P.; Mariotto, S.; Cellini, B.; et al. Mutant p53 proteins counteract autophagic mechanism sensitizing cancer cells to mTOR inhibition. Mol. Oncol. 2016, 10, 1008-1029. [CrossRef] [PubMed]

65. Aggarwal, M.; Saxena, R.; Sinclair, E.; Fu, Y.; Jacobs, A.; Dyba, M.; Wang, X.; Cruz, I.; Berry, D.; Kallakury, B.; et al. Reactivation of mutant $\mathrm{p} 53$ by a dietary-related compound phenethyl isothiocyanate inhibits tumor growth. Cell Death Differ. 2016, 23, 1615-1627. [CrossRef] [PubMed]

66. Di Agostino, S.; Cortese, G.; Monti, O.; Dell'Orso, S.; Sacchi, A.; Eisenstein, M.; Citro, G.; Strano, S.; Blandino, G. The disruption of the protein complex mutantp53/p73 increases selectively the response of tumor cells to anticancer drugs. Cell Cycle 2008, 7, 3440-3447. [CrossRef] [PubMed]

67. Liu, X.; Wilcken, R.; Joerger, A.C.; Chuckowree, I.S.; Amin, J.; Spencer, J.; Fersht, A.R. Small molecule induced reactivation of mutant p53 in cancer cells. Nucleic Acids Res. 2013, 41, 6034-6044. [CrossRef] [PubMed]

68. Goldenson, B.; Crispino, J.D. The aurora kinases in cell cycle and leukemia. Oncogene 2015, 34, 537-545. [CrossRef] [PubMed]

69. Nikonova, A.S.; Astsaturov, I.; Serebriiskii, I.G.; Dunbrack, R.L.; Golemis, E.A. Aurora-A kinase (AURKA) in normal and pathological cell growth. Cell. Mol. Life Sci. 2013, 70, 661-687. [CrossRef] [PubMed]

70. Guan, Z.; Wang, X.R.; Zhu, X.F.; Huang, X.F.; Xu, J.; Wang, L.H.; Wan, X.B.; Long, Z.J.; Liu, J.N.; Feng, G.K.; et al. Aurora-A, a negative prognostic marker, increases migration and decreases radiosensitivity in cancer cells. Cancer Res. 2007, 67, 10436-10444. [CrossRef] [PubMed]

71. Oh, E.T.; Byun, M.S.; Lee, H.; Park, M.T.; Jue, D.M.; Lee, C.W.; Lim, B.U.; Park, H.J. Aurora-a contributes to radioresistance by increasing NF-kappaB DNA binding. Radiat. Res. 2010, 174, 265-273. [CrossRef] [PubMed]

72. Thollet, A.; Vendrell, J.A.; Payen, L.; Ghayad, S.E.; Ben Larbi, S.; Grisard, E.; Collins, C.; Villedieu, M.; Cohen, P.A. ZNF217 confers resistance to the pro-apoptotic signals of paclitaxel and aberrant expression of Aurora-A in breast cancer cells. Mol. Cancer 2010, 9, 291. [CrossRef] [PubMed]

73. Zhang, K.; Chen, J.; Chen, D.; Huang, J.; Feng, B.; Han, S.; Chen, Y.; Song, H.; De, W.; Zhu, Z.; et al. Aurora-A promotes chemoresistance in hepatocelluar carcinoma by targeting NF-kappaB/microRNA-21/PTEN signaling pathway. Oncotarget 2014, 5, 12916-12935. [CrossRef] [PubMed]

74. Yang, H.; He, L.; Kruk, P.; Nicosia, S.V.; Cheng, J.Q. Aurora-A induces cell survival and chemoresistance by activation of Akt through a p53-dependent manner in ovarian cancer cells. Int. J. Cancer 2006, 119, 2304-2312. [CrossRef] [PubMed]

75. Sun, H.; Wang, Y.; Wang, Z.; Meng, J.; Qi, Z.; Yang, G. Aurora-A controls cancer cell radio- and chemoresistance via ATM/Chk2-mediated DNA repair networks. Biochim. Biophys. Acta 2014, 1843, 934-944. [CrossRef] [PubMed]

76. Kelly, K.R.; Nawrocki, S.T.; Espitia, C.M.; Zhang, M.; Yang, J.J.; Padmanabhan, S.; Ecsedy, J.; Giles, F.J.; Carew, J.S. Targeting Aurora A kinase activity with the investigational agent alisertib increases the efficacy of cytarabine through a FOXO-dependent mechanism. Int. J. Cancer 2012, 131, 2693-2703. [CrossRef] [PubMed]

77. Kelly, K.R.; Ecsedy, J.; Medina, E.; Mahalingam, D.; Padmanabhan, S.; Nawrocki, S.T.; Giles, F.J.; Carew, J.S. The novel Aurora A kinase inhibitor MLN8237 is active in resistant chronic myeloid leukaemia and significantly increases the efficacy of nilotinib. J. Cell. Mol. Med. 2011, 15, 2057-2070. [CrossRef] [PubMed]

78. Chefetz, I.; Holmberg, J.C.; Alvero, A.B.; Visintin, I.; Mor, G. Inhibition of Aurora-A kinase induces cell cycle arrest in epithelial ovarian cancer stem cells by affecting NFkB pathway. Cell Cycle 2011, 10, 2206-2214. [CrossRef] [PubMed] 
79. Narod, S.A.; Foulkes, W.D. BRCA1 and BRCA2: 1994 and beyond. Nat. Rev. Cancer 2004, 4, 665-676. [CrossRef] [PubMed]

80. Kadouri, L.; Hubert, A.; Rotenberg, Y.; Hamburger, T.; Sagi, M.; Nechushtan, C.; Abeliovich, D.; Peretz, T. Cancer risks in carriers of the BRCA1/2 Ashkenazi founder mutations. J. Med. Genet. 2007, 44, 467-471. [CrossRef] [PubMed]

81. Venkitaraman, A.R. Tracing the network connecting BRCA and Fanconi anaemia proteins. Nat. Rev. Cancer 2004, 4, 266-276. [CrossRef] [PubMed]

82. D'Andrea, A.D.; Grompe, M. The Fanconi anaemia/BRCA pathway. Nat. Rev. Cancer 2003, 3, $23-34$. [CrossRef] [PubMed]

83. Farmer, H.; McCabe, N.; Lord, C.J.; Tutt, A.N.; Johnson, D.A.; Richardson, T.B.; Santarosa, M.; Dillon, K.J.; Hickson, I.; Knights, C.; et al. Targeting the DNA repair defect in BRCA mutant cells as a therapeutic strategy. Nature 2005, 434, 917-921. [CrossRef] [PubMed]

84. Bryant, H.E.; Schultz, N.; Thomas, H.D.; Parker, K.M.; Flower, D.; Lopez, E.; Kyle, S.; Meuth, M.; Curtin, N.J.; Helleday, T. Specific killing of BRCA2-deficient tumours with inhibitors of poly(ADP-ribose) polymerase. Nature 2005, 434, 913-917. [CrossRef] [PubMed]

85. Sakai, W.; Swisher, E.M.; Jacquemont, C.; Chandramohan, K.V.; Couch, F.J.; Langdon, S.P.; Wurz, K.; Higgins, J.; Villegas, E.; Taniguchi, T. Functional restoration of BRCA2 protein by secondary BRCA2 mutations in BRCA2-mutated ovarian carcinoma. Cancer Res. 2009, 69, 6381-6386. [CrossRef] [PubMed]

86. Dhillon, K.K.; Swisher, E.M.; Taniguchi, T. Secondary mutations of BRCA1/2 and drug resistance. Cancer Sci. 2011, 102, 663-669. [CrossRef] [PubMed]

87. Wiltshire, T.; Senft, J.; Wang, Y.; Konat, G.W.; Wenger, S.L.; Reed, E.; Wang, W. BRCA1 contributes to cell cycle arrest and chemoresistance in response to the anticancer agent irofulven. Mol. Pharmacol. 2007, 71, 1051-1060. [CrossRef] [PubMed]

88. Huang, F.; Goyal, N.; Sullivan, K.; Hanamshet, K.; Patel, M.; Mazina, O.M.; Wang, C.X.; An, W.F.; Spoonamore, J.; Metkar, S.; et al. Targeting BRCA1- and BRCA2-deficient cells with RAD52 small molecule inhibitors. Nucleic Acids Res. 2016, 44, 4189-4199. [CrossRef] [PubMed]

89. Dziadkowiec, K.N.; Gasiorowska, E.; Nowak-Markwitz, E.; Jankowska, A. PARP inhibitors: Review of mechanisms of action and BRCA1/2 mutation targeting. Prz. Menopauzalny 2016, 15, 215-219. [CrossRef] [PubMed]

90. Wei, W.; Sun, H.H.; Li, N.; Li, H.Y.; Li, X.; Li, Q.; Shen, X.H. WNT5A modulates cell cycle progression and contributes to the chemoresistance in pancreatic cancer cells. Hepatobiliary Pancreat. Dis. Int. 2014, 13, 529-538. [CrossRef]

91. Asem, M.S.; Buechler, S.; Wates, R.B.; Miller, D.L.; Stack, M.S. Wnt5a Signaling in Cancer. Cancers 2016, 8, 79. [CrossRef] [PubMed]

92. Medrek, C.; Landberg, G.; Andersson, T.; Leandersson, K. Wnt-5a-CKI $\alpha$ signaling promotes $\beta$-catenin/E-cadherin complex formation and intercellular adhesion in human breast epithelial cells. J. Biol. Chem. 2009, 284, 10968-10979. [CrossRef] [PubMed]

93. Yamamoto, H.; Oue, N.; Sato, A.; Hasegawa, Y.; Matsubara, A.; Yasui, W.; Kikuchi, A. Wnt5a signaling is involved in the aggressiveness of prostate cancer and expression of metalloproteinase. Oncogene 2010, 29, 2036-2046. [CrossRef] [PubMed]

94. Da Forno, P.D.; Pringle, J.H.; Hutchinson, P.; Osborn, J.; Huang, Q.; Potter, L.; Hancox, R.A.; Fletcher, A.; Saldanha, G.S. WNT5A expression increases during melanoma progression and correlates with outcome. Clin. Cancer Res. 2008, 14, 5825-5832. [CrossRef] [PubMed]

95. Anastas, J.N.; Kulikauskas, R.M.; Tamir, T.; Rizos, H.; Long, G.V.; von Euw, E.M.; Yang, P.T.; Chen, H.W.; Haydu, L.; Toroni, R.A.; et al. WNT5A enhances resistance of melanoma cells to targeted BRAF inhibitors. J. Clin. Investig. 2014, 124, 2877-2890. [CrossRef] [PubMed]

96. Dissanayake, S.K.; Weeraratna, A.T. Detecting PKC phosphorylation as part of the Wnt/calcium pathway in cutaneous melanoma. Methods Mol. Biol. 2008, 468, 157-172. [CrossRef] [PubMed]

97. Yang, J.; Zhang, K.; Wu, J.; Shi, J.; Xue, J.; Li, J.; Chen, J.; Zhu, Y.; Wei, J.; He, J.; et al. Wnt5a Increases Properties of Lung Cancer Stem Cells and Resistance to Cisplatin through Activation of Wnt5a/PKC Signaling Pathway. Stem Cells Int. 2016, 2016, 1690896. [CrossRef] [PubMed] 
98. Griesmann, H.; Ripka, S.; Pralle, M.; Ellenrieder, V.; Baumgart, S.; Buchholz, M.; Pilarsky, C.; Aust, D.; Gress, T.M.; Michl, P. WNT5A-NFAT signaling mediates resistance to apoptosis in pancreatic cancer. Neoplasia 2013, 15, 11-22. [CrossRef] [PubMed]

99. Sanchez-Prieto, R.; Rojas, J.M.; Taya, Y.; Gutkind, J.S. A role for the p38 mitogen-acitvated protein kinase pathway in the transcriptional activation of p53 on genotoxic stress by chemotherapeutic agents. Cancer Res. 2000, 60, 2464-2472. [PubMed]

100. Cai, B.; Chang, S.H.; Becker, E.B.; Bonni, A.; Xia, Z. p38 MAP kinase mediates apoptosis through phosphorylation of BimEL at Ser-65. J. Biol. Chem. 2006, 281, 25215-25222. [CrossRef] [PubMed]

101. Manke, I.A.; Nguyen, A.; Lim, D.; Stewart, M.Q.; Elia, A.E.; Yaffe, M.B. MAPKAP kinase-2 is a cell cycle checkpoint kinase that regulates the $\mathrm{G} 2 / \mathrm{M}$ transition and $\mathrm{S}$ phase progression in response to UV irradiation. Mol. Cell 2005, 17, 37-48. [CrossRef] [PubMed]

102. Reinhardt, H.C.; Aslanian, A.S.; Lees, J.A.; Yaffe, M.B. p53-deficient cells rely on ATM- and ATR-mediated checkpoint signaling through the p38MAPK/MK2 pathway for survival after DNA damage. Cancer Cell 2007, 11, 175-189. [CrossRef] [PubMed]

103. Pan, S.T.; Li, Z.L.; He, Z.X.; Qiu, J.X.; Zhou, S.F. Molecular mechanisms for tumour resistance to chemotherapy. Clin. Exp. Pharmacol. Physiol. 2016, 43, 723-737. [CrossRef] [PubMed]

104. Igea, A.; Nebreda, A.R. The Stress Kinase p38 $\alpha$ as a Target for Cancer Therapy. Cancer Res. 2015, 75, 3997-4002. [CrossRef] [PubMed]

105. Mikhailov, A.; Shinohara, M.; Rieder, C.L. Topoisomerase II and histone deacetylase inhibitors delay the G2/M transition by triggering the p38 MAPK checkpoint pathway. J. Cell Biol. 2004, 166, 517-526. [CrossRef] [PubMed]

106. Mikhailov, A.; Shinohara, M.; Rieder, C.L. The p38-mediated stress-activated checkpoint. A rapid response system for delaying progression through antephase and entry into mitosis. Cell Cycle 2005, 4, 57-62. [CrossRef] [PubMed]

107. Bucher, N.; Britten, C.D. G2 checkpoint abrogation and checkpoint kinase-1 targeting in the treatment of cancer. Br. J. Cancer 2008, 98, 523-528. [CrossRef] [PubMed]

108. Morandell, S.; Reinhardt, H.C.; Cannell, I.G.; Kim, J.S.; Ruf, D.M.; Mitra, T.; Couvillon, A.D.; Jacks, T.; Yaffe, M.B. A reversible gene-targeting strategy identifies synthetic lethal interactions between MK2 and p53 in the DNA damage response in vivo. Cell Rep. 2013, 5, 868-877. [CrossRef] [PubMed]

109. Tan, W.; Yu, H.G.; Luo, H.S. Inhibition of the p38 MAPK pathway sensitizes human gastric cells to doxorubicin treatment in vitro and in vivo. Mol. Med. Rep. 2014, 10, 3275-3281. [CrossRef] [PubMed]

110. Paillas, S.; Boissiere, F.; Bibeau, F.; Denouel, A.; Mollevi, C.; Causse, A.; Denis, V.; Vezzio-Vie, N.; Marzi, L.; Cortijo, C.; et al. Targeting the p38 MAPK pathway inhibits irinotecan resistance in colon adenocarcinoma. Cancer Res. 2011, 71, 1041-1049. [CrossRef] [PubMed]

111. Kopper, F.; Binkowski, A.M.; Bierwirth, C.; Dobbelstein, M. The MAPK-activated protein kinase 2 mediates gemcitabine sensitivity in pancreatic cancer cells. Cell Cycle 2014, 13, 884-889. [CrossRef] [PubMed]

112. Gu, C.; Cheng, H.; Yang, H.; Bian, Y.; Wang, Y.; Zhang, Y.; Pisano, M.; Hu, G.; Yang, Y. MK2 is a therapeutic target for high-risk multiple myeloma. Haematologica 2018, 103. [CrossRef] [PubMed]

113. Walczak, H. Death receptor-ligand systems in cancer, cell death, and inflammation. Cold Spring Harb. Perspect. Biol. 2013, 5, a008698. [CrossRef] [PubMed]

114. Kurokawa, M.; Kornbluth, S. Caspases and kinases in a death grip. Cell 2009, 138, 838-854. [CrossRef] [PubMed]

115. Shamas-Din, A.; Brahmbhatt, H.; Leber, B.; Andrews, D.W. BH3-only proteins: Orchestrators of apoptosis. Biochim. Biophys. Acta 2011, 1813, 508-520. [CrossRef] [PubMed]

116. Li, H.; Zhu, H.; Xu, C.J.; Yuan, J. Cleavage of BID by caspase 8 mediates the mitochondrial damage in the Fas pathway of apoptosis. Cell 1998, 94, 491-501. [CrossRef]

117. LaCasse, E.C.; Mahoney, D.J.; Cheung, H.H.; Plenchette, S.; Baird, S.; Korneluk, R.G. IAP-targeted therapies for cancer. Oncogene 2008, 27, 6252-6275. [CrossRef] [PubMed]

118. Sadarangani, A.; Kato, S.; Espinoza, N.; Lange, S.; Llados, C.; Espinosa, M.; Villalon, M.; Lipkowitz, S.; Cuello, M.; Owen, G.I. TRAIL mediates apoptosis in cancerous but not normal primary cultured cells of the human reproductive tract. Apoptosis 2007, 12, 73-85. [CrossRef] [PubMed]

119. Trivedi, R.; Mishra, D.P. Trailing TRAIL Resistance: Novel Targets for TRAIL Sensitization in Cancer Cells. Front. Oncol. 2015, 5, 69. [CrossRef] [PubMed] 
120. Twomey, J.D.; Kim, S.-R.; Zhao, L.; Bozza, W.P.; Zhang, B. Spatial dynamics of TRAIL death receptors in cancer cells. Drug Resist. Updates 2015, 19, 13-21. [CrossRef] [PubMed]

121. Yoon, M.J.; Kang, Y.J.; Kim, I.Y.; Kim, E.H.; Lee, J.A.; Lim, J.H.; Kwon, T.K.; Choi, K.S. Monensin, a polyether ionophore antibiotic, overcomes TRAIL resistance in glioma cells via endoplasmic reticulum stress, DR5 upregulation and c-FLIP downregulation. Carcinogenesis 2013, 34, 1918-1928. [CrossRef] [PubMed]

122. Trivedi, R.; Maurya, R.; Mishra, D.P. Medicarpin, a legume phytoalexin sensitizes myeloid leukemia cells to TRAIL-induced apoptosis through the induction of DR5 and activation of the ROS-JNK-CHOP pathway. Cell Death Dis. 2014, 5, e1465. [CrossRef] [PubMed]

123. Murai, M.; Inoue, T.; Suzuki-Karasaki, M.; Ochiai, T.; Ra, C.; Nishida, S.; Suzuki-Karasaki, Y. Diallyl trisulfide sensitizes human melanoma cells to TRAIL-induced cell death by promoting endoplasmic reticulum-mediated apoptosis. Int. J. Oncol. 2012, 41, 2029-2037. [CrossRef] [PubMed]

124. Jiang, C.C.; Chen, L.H.; Gillespie, S.; Kiejda, K.A.; Mhaidat, N.; Wang, Y.F.; Thorne, R.; Zhang, X.D.; Hersey, P. Tunicamycin sensitizes human melanoma cells to tumor necrosis factor-related apoptosis-inducing ligand-induced apoptosis by up-regulation of TRAIL-R2 via the unfolded protein response. Cancer Res. 2007, 67, 5880-5888. [CrossRef] [PubMed]

125. Yang, J.F.; Cao, J.G.; Tian, L.; Liu, F. 5,7-Dimethoxyflavone sensitizes TRAIL-induced apoptosis through DR5 upregulation in hepatocellular carcinoma cells. Cancer Chemother. Pharmacol. 2012, 69, 195-206. [CrossRef] [PubMed]

126. Kandasamy, K.; Kraft, A.S. Proteasome inhibitor PS-341 (VELCADE) induces stabilization of the TRAIL receptor DR5 mRNA through the 3'-untranslated region. Mol. Cancer Ther. 2008, 7, 1091-1100. [CrossRef] [PubMed]

127. Ma, Y.; Lakshmikanthan, V.; Lewis, R.W.; Kumar, M.V. Sensitization of TRAIL-resistant cells by inhibition of heat shock protein 90 with low-dose geldanamycin. Mol. Cancer Ther. 2006, 5, 170-178. [CrossRef] [PubMed]

128. Siegelin, M.D.; Habel, A.; Gaiser, T. 17-AAG sensitized malignant glioma cells to death-receptor mediated apoptosis. Neurobiol. Dis. 2009, 33, 243-249. [CrossRef] [PubMed]

129. Mellier, G.; Liu, D.; Bellot, G.; Holme, A.L.; Pervaiz, S. Small molecule sensitization to TRAIL is mediated via nuclear localization, phosphorylation and inhibition of chaperone activity of Hsp27. Cell Death Dis. 2013, 4, e890. [CrossRef] [PubMed]

130. Zhao, J.; Lu, Y.; Shen, H.-M. Targeting p53 as a therapeutic strategy in sensitizing TRAIL-induced apoptosis in cancer cells. Cancer Lett. 2012, 314, 8-23. [CrossRef] [PubMed]

131. Hou, W.; Han, J.; Lu, C.; Goldstein, L.A.; Rabinowich, H. Enhancement of tumor-TRAIL susceptibility by modulation of autophagy. Autophagy 2008, 4, 940-943. [CrossRef] [PubMed]

132. Hernandez, A.; Wang, Q.D.; Schwartz, S.A.; Evers, B.M. Sensitization of human colon cancer cells to TRAIL-mediated apoptosis. J. Gastrointest. Surg. 2001, 5, 56-65. [CrossRef]

133. Kim, H.B.; Kim, M.J.; Lee, S.H.; Lee, J.W.; Bae, J.H.; Kim, D.W.; Dao, T.T.; Oh, W.K.; Kang, C.D.; Kim, S.H. Amurensin G, a novel SIRT1 inhibitor, sensitizes TRAIL-resistant human leukemic K562 cells to TRAIL-induced apoptosis. Biochem. Pharmacol. 2012, 84, 402-410. [CrossRef] [PubMed]

134. Ueffing, N.; Keil, E.; Freund, C.; Kühne, R.; Schulze-Osthoff, K.; Schmitz, I. Mutational analyses of c-FLIPR, the only murine short FLIP isoform, reveal requirements for DISC recruitment. Cell Death Differ. 2008, 15, 773-782. [CrossRef] [PubMed]

135. Thome, M.; Schneider, P.; Hofmann, K.; Fickenscher, H.; Meinl, E.; Neipel, F.; Mattmann, C.; Burns, K.; Bodmer, J.L.; Schroter, M.; et al. Viral FLICE-inhibitory proteins (FLIPs) prevent apoptosis induced by death receptors. Nature 1997, 386, 517-521. [CrossRef] [PubMed]

136. Kataoka, T.; Ito, M.; Budd, R.C.; Tschopp, J.; Nagai, K. Expression level of c-FLIP versus Fas determines susceptibility to Fas ligand-induced cell death in murine thymoma EL-4 cells. Exp. Cell Res. 2002, 273, 256-264. [CrossRef] [PubMed]

137. Wilson, T.R.; McLaughlin, K.M.; McEwan, M.; Sakai, H.; Rogers, K.M.; Redmond, K.M.; Johnston, P.G.; Longley, D.B. c-FLIP: A key regulator of colorectal cancer cell death. Cancer Res. 2007, 67, 5754-5762. [CrossRef] [PubMed]

138. El-Gazzar, A.; Wittinger, M.; Perco, P.; Anees, M.; Horvat, R.; Mikulits, W.; Grunt, T.W.; Mayer, B.; Krainer, M. The role of c-FLIP(L) in ovarian cancer: Chaperoning tumor cells from immunosurveillance and increasing their invasive potential. Gynecol. Oncol. 2010, 117, 451-459. [CrossRef] [PubMed] 
139. Haag, C.; Stadel, D.; Zhou, S.; Bachem, M.G.; Moller, P.; Debatin, K.M.; Fulda, S. Identification of c-FLIP(L) and c-FLIP(S) as critical regulators of death receptor-induced apoptosis in pancreatic cancer cells. Gut 2011, 60, 225-237. [CrossRef] [PubMed]

140. Ullenhag, G.J.; Mukherjee, A.; Watson, N.F.; Al-Attar, A.H.; Scholefield, J.H.; Durrant, L.G. Overexpression of FLIPL is an independent marker of poor prognosis in colorectal cancer patients. Clin. Cancer Res. 2007, 13, 5070-5075. [CrossRef] [PubMed]

141. Shirley, S.; Micheau, O. Targeting c-FLIP in cancer. Cancer Lett. 2013, 332, 141-150. [CrossRef] [PubMed]

142. Wilson, C.; Wilson, T.; Johnston, P.G.; Longley, D.B.; Waugh, D.J. Interleukin-8 signaling attenuates TRAILand chemotherapy-induced apoptosis through transcriptional regulation of c-FLIP in prostate cancer cells. Mol. Cancer Ther. 2008, 7, 2649-2661. [CrossRef] [PubMed]

143. Seo, S.U.; Cho, H.K.; Min, K.-J.; Woo, S.M.; Kim, S.; Park, J.-W.; Kim, S.H.; Choi, Y.H.; Keum, Y.S.; Hyun, J.W.; et al. Thioridazine enhances sensitivity to carboplatin in human head and neck cancer cells through downregulation of c-FLIP and Mcl-1 expression. Cell Death Dis. 2017, 8, e2599. [CrossRef] [PubMed]

144. Kauh, J.; Fan, S.; Xia, M.; Yue, P.; Yang, L.; Khuri, F.R.; Sun, S.Y. c-FLIP degradation mediates sensitization of pancreatic cancer cells to TRAIL-induced apoptosis by the histone deacetylase inhibitor LBH589. PLoS ONE 2010, 5, e10376. [CrossRef] [PubMed]

145. Henrich, C.J.; Brooks, A.D.; Erickson, K.L.; Thomas, C.L.; Bokesch, H.R.; Tewary, P.; Thompson, C.R.; Pompei, R.J.; Gustafson, K.R.; McMahon, J.B.; et al. Withanolide E sensitizes renal carcinoma cells to TRAIL-induced apoptosis by increasing cFLIP degradation. Cell Death Dis. 2015, 6, e1666. [CrossRef] [PubMed]

146. Kolar, Z.; Murray, P.G.; Scott, K.; Harrison, A.; Vojtesek, B.; Dusek, J. Relation of Bcl-2 expression to androgen receptor, p21WAF1/CIP1, and cyclin D1 status in prostate cancer. Mol. Pathol. 2000, 53, 15-18. [CrossRef] [PubMed]

147. Chen, J.; Jin, S.; Abraham, V.; Huang, X.; Liu, B.; Mitten, M.J.; Nimmer, P.; Lin, X.; Smith, M.; Shen, Y.; et al. The Bcl-2/Bcl-X(L)/Bcl-w inhibitor, navitoclax, enhances the activity of chemotherapeutic agents in vitro and in vivo. Mol. Cancer Ther. 2011, 10, 2340-2349. [CrossRef] [PubMed]

148. Scherr, A.L.; Gdynia, G.; Salou, M.; Radhakrishnan, P.; Duglova, K.; Heller, A.; Keim, S.; Kautz, N.; Jassowicz, A.; Elssner, C.; et al. Bcl-xL is an oncogenic driver in colorectal cancer. Cell Death Dis. 2016, 7, e2342. [CrossRef] [PubMed]

149. Kotschy, A.; Szlavik, Z.; Murray, J.; Davidson, J.; Maragno, A.L.; Le Toumelin-Braizat, G.; Chanrion, M.; Kelly, G.L.; Gong, J.N.; Moujalled, D.M.; et al. The MCL1 inhibitor 563845 is tolerable and effective in diverse cancer models. Nature 2016, 538, 477-482. [CrossRef] [PubMed]

150. Bruncko, M.; Wang, L.; Sheppard, G.S.; Phillips, D.C.; Tahir, S.K.; Xue, J.; Erickson, S.; Fidanze, S.; Fry, E.; Hasvold, L.; et al. Structure-guided design of a series of MCL-1 inhibitors with high affinity and selectivity. J. Med. Chem. 2015, 58, 2180-2194. [CrossRef] [PubMed]

151. Bittker, J.A.; Weiwer, M.; Wei, G.; Germain, A.; Brown, E.; Dandapani, S.; Munoz, B.; Palmer, M.; Golub, T.; Schreiber, S.L. Discovery of inhibitors of anti-apoptotic protein A1. In Probe Reports from the NIH Molecular Libraries Program; National Center for Biotechnology Information (US): Bethesda, MD, USA, 2010.

152. Pluta, P.; Jeziorski, A.; Cebula-Obrzut, A.P.; Wierzbowska, A.; Piekarski, J.; Smolewski, P. Expression of IAP family proteins and its clinical importance in breast cancer patients. Neoplasma 2015, 62, 666-673. [CrossRef] [PubMed]

153. Endo, T.; Abe, S.; Seidlar, H.B.; Nagaoka, S.; Takemura, T.; Utsuyama, M.; Kitagawa, M.; Hirokawa, K. Expression of IAP family proteins in colon cancers from patients with different age groups. Cancer Immunol. Immunother. 2004, 53, 770-776. [CrossRef] [PubMed]

154. Nemoto, T.; Kitagawa, M.; Hasegawa, M.; Ikeda, S.; Akashi, T.; Takizawa, T.; Hirokawa, K.; Koike, M. Expression of IAP family proteins in esophageal cancer. Exp. Mol. Pathol. 2004, 76, 253-259. [CrossRef] [PubMed]

155. Espinosa, M.; Cantu, D.; Herrera, N.; Lopez, C.M.; De la Garza, J.G.; Maldonado, V.; Melendez-Zajgla, J. Inhibitors of apoptosis proteins in human cervical cancer. BMC Cancer 2006, 6, 45. [CrossRef] [PubMed]

156. Moon, J.-H.; Shin, J.-S.; Hong, S.-W.; Jung, S.-A.; Hwang, I.-Y.; Kim, J.H.; Choi, E.K.; Ha, S.-H.; Kim, J.-S.; Kim, K.-M.; et al. A novel small-molecule IAP antagonist, AZD5582, draws Mcl-1 down-regulation for induction of apoptosis through targeting of cIAP1 and XIAP in human pancreatic cancer. Oncotarget 2015, 6, 26895-26908. [CrossRef] [PubMed] 
157. LaCasse, E.C.; Cherton-Horvat, G.G.; Hewitt, K.E.; Jerome, L.J.; Morris, S.J.; Kandimalla, E.R.; Yu, D.; Wang, H.; Wang, W.; Zhang, R.; et al. Preclinical Characterization of AEG35156/GEM 640, a Second-Generation Antisense Oligonucleotide Targeting X-Linked Inhibitor of Apoptosis. Clin. Cancer Res. 2006, 12, 5231-5241. [CrossRef] [PubMed]

158. Dean, E.; Jodrell, D.; Connolly, K.; Danson, S.; Jolivet, J.; Durkin, J.; Morris, S.; Jowle, D.; Ward, T.; Cummings, J.; et al. Phase I trial of AEG35156 administered as a 7-day and 3-day continuous intravenous infusion in patients with advanced refractory cancer. J. Clin. Oncol 2009, 27, 1660-1666. [CrossRef] [PubMed]

159. Gyuraszova, K.; Mikes, J.; Halaburkova, A.; Jendzelovsky, R.; Fedorocko, P. YM155, a small molecule inhibitor of survivin expression, sensitizes cancer cells to hypericin-mediated photodynamic therapy. Photochem. Photobiol. Sci. 2016, 15, 812-821. [CrossRef] [PubMed]

160. Foster, F.; Owens, T.; Tanianis-Hughes, J.; Clarke, R.; Brennan, K.; Bundred, N.; Streuli, C. Targeting inhibitor of apoptosis proteins in combination with ErbB antagonists in breast cancer. Breast Cancer Res. 2009, 11, R41. [CrossRef] [PubMed]

161. Fandy, T.E.; Shankar, S.; Srivastava, R.K. Smac/DIABLO enhances the therapeutic potential of chemotherapeutic drugs and irradiation, and sensitizes TRAIL-resistant breast cancer cells. Mol. Cancer 2008, 7, 60. [CrossRef] [PubMed]

162. Ziegler, D.S.; Wright, R.D.; Kesari, S.; Lemieux, M.E.; Tran, M.A.; Jain, M.; Zawel, L.; Kung, A.L. Resistance of human glioblastoma multiforme cells to growth factor inhibitors is overcome by blockade of inhibitor of apoptosis proteins. J. Clin. Investig. 2008, 118, 3109-3122. [CrossRef] [PubMed]

163. Weisberg, E.; Kung, A.L.; Wright, R.D.; Moreno, D.; Catley, L.; Ray, A.; Zawel, L.; Tran, M.; Cools, J.; Gilliland, G.; et al. Potentiation of antileukemic therapies by Smac mimetic, LBW242: Effects on mutant FLT3-expressing cells. Mol. Cancer Ther. 2007, 6, 1951-1961. [CrossRef] [PubMed]

164. Weisberg, E.; Ray, A.; Barrett, R.; Nelson, E.; Christie, A.L.; Porter, D.; Straub, C.; Zawel, L.; Daley, J.F.; Lazo-Kallanian, S.; et al. Smac mimetics: Implications for enhancement of targeted therapies in leukemia. Leukemia 2010, 24, 2100-2109. [CrossRef] [PubMed]

165. Kim, E.-A.; Kim, S.-W.; Nam, J.; Sung, E.-G.; Song, I.-H.; Kim, J.-Y.; Kwon, T.K.; Lee, T.-J. Inhibition of c-FLIP(L) expression by miRNA-708 increases the sensitivity of renal cancer cells to anti-cancer drugs. Oncotarget 2016, 7, 31832-31846. [CrossRef] [PubMed]

166. Herman, M.D.; Nyman, T.; Welin, M.; Lehtio, L.; Flodin, S.; Tresaugues, L.; Kotenyova, T.; Flores, A.; Nordlund, P. Completing the family portrait of the anti-apoptotic Bcl-2 proteins: Crystal structure of human Bfl-1 in complex with Bim. FEBS Lett. 2008, 582, 3590-3594. [CrossRef] [PubMed]

167. Deveraux, Q.L.; Takahashi, R.; Salvesen, G.S.; Reed, J.C. X-linked IAP is a direct inhibitor of cell-death proteases. Nature 1997, 388, 300-304. [CrossRef] [PubMed]

168. Bai, L.; Smith, D.C.; Wang, S. Small-Molecule SMAC Mimetics as New Cancer Therapeutics. Pharmacol. Ther. 2014, 144, 82-95. [CrossRef] [PubMed]

169. Galbán, S.; Hwang, C.; Rumble, J.M.; Oetjen, K.A.; Wright, C.W.; Boudreault, A.; Durkin, J.; Gillard, J.W.; Jaquith, J.B.; Morris, S.J.; et al. Cytoprotective effects of iaps revealed by a small molecule antagonist. Biochem. J. 2009, 417, 765-771. [CrossRef] [PubMed]

170. Marusawa, H.; Matsuzawa, S.; Welsh, K.; Zou, H.; Armstrong, R.; Tamm, I.; Reed, J.C. HBXIP functions as a cofactor of survivin in apoptosis suppression. EMBO J. 2003, 22, 2729-2740. [CrossRef] [PubMed]

171. Song, Z.; Yao, X.; Wu, M. Direct interaction between survivin and Smac/DIABLO is essential for the anti-apoptotic activity of survivin during taxol-induced apoptosis. J. Biol. Chem. 2003, 278, 23130-23140. [CrossRef] [PubMed]

172. Partridge, M.; Green, M.R.; Langdon, J.D.; Feldmann, M. Production of TGF- $\alpha$ and TGF- $\beta$ by cultured keratinocytes, skin and oral squamous cell carcinomas-potential autocrine regulation of normal and malignant epithelial cell proliferation. Br. J. Cancer 1989, 60, 542-548. [CrossRef] [PubMed]

173. Imamura, T.; Hikita, A.; Inoue, Y. The roles of TGF- $\beta$ signaling in carcinogenesis and breast cancer metastasis. Breast Cancer 2012, 19, 118-124. [CrossRef] [PubMed]

174. Du, B.; Shim, J.S. Targeting Epithelial-Mesenchymal Transition (EMT) to Overcome Drug Resistance in Cancer. Molecules 2016, 21. [CrossRef] [PubMed]

175. Colak, S.; Ten Dijke, P. Targeting TGF- $\beta$ Signaling in Cancer. Trends Cancer 2017, 3, 56-71. [CrossRef] [PubMed] 
176. Roy, L.O.; Poirier, M.B.; Fortin, D. Differential Expression and Clinical Significance of Transforming Growth Factor- $\beta$ Isoforms in GBM Tumors. Int. J. Mol. Sci. 2018, 19. [CrossRef] [PubMed]

177. Mao, L.; Li, Y.; Zhao, J.; Li, Q.; Yang, B.; Wang, Y.; Zhu, Z.; Sun, H.; Zhai, Z. Transforming growth factor- $\beta 1$ contributes to oxaliplatin resistance in colorectal cancer via epithelial to mesenchymal transition. Oncol. Lett. 2017, 14, 647-654. [CrossRef] [PubMed]

178. Li, J.; Liu, H.; Yu, J.; Yu, H. Chemoresistance to doxorubicin induces epithelial-mesenchymal transition via upregulation of transforming growth factor $\beta$ signaling in HCT116 colon cancer cells. Mol. Med. Rep. 2015, 12, 192-198. [CrossRef] [PubMed]

179. Saxena, M.; Stephens, M.A.; Pathak, H.; Rangarajan, A. Transcription factors that mediate epithelial-mesenchymal transition lead to multidrug resistance by upregulating $\mathrm{ABC}$ transporters. Cell Death Dis. 2011, 2, e179. [CrossRef] [PubMed]

180. Bhola, N.E.; Balko, J.M.; Dugger, T.C.; Kuba, M.G.; Sanchez, V.; Sanders, M.; Stanford, J.; Cook, R.S.; Arteaga, C.L. TGF- $\beta$ inhibition enhances chemotherapy action against triple-negative breast cancer. J. Clin. Investig. 2013, 123, 1348-1358. [CrossRef] [PubMed]

181. Park, C.Y.; Son, J.Y.; Jin, C.H.; Nam, J.S.; Kim, D.K.; Sheen, Y.Y. EW-7195, a novel inhibitor of ALK5 kinase inhibits EMT and breast cancer metastasis to lung. Eur. J. Cancer 2011, 47, 2642-2653. [CrossRef] [PubMed]

182. Park, C.Y.; Kim, D.K.; Sheen, Y.Y. EW-7203, a novel small molecule inhibitor of transforming growth factor- $\beta$ (TGF- $\beta$ ) type I receptor/activin receptor-like kinase-5, blocks TGF- $\beta 1$-mediated epithelial-to-mesenchymal transition in mammary epithelial cells. Cancer Sci. 2011, 102, 1889-1896. [CrossRef] [PubMed]

183. Park, C.Y.; Min, K.N.; Son, J.Y.; Park, S.Y.; Nam, J.S.; Kim, D.K.; Sheen, Y.Y. An novel inhibitor of TGF- $\beta$ type I receptor, IN-1130, blocks breast cancer lung metastasis through inhibition of epithelial-mesenchymal transition. Cancer Lett. 2014, 351, 72-80. [CrossRef] [PubMed]

184. Serova, M.; Tijeras-Raballand, A.; Dos Santos, C.; Albuquerque, M.; Paradis, V.; Neuzillet, C.; Benhadji, K.A.; Raymond, E.; Faivre, S.; de Gramont, A. Effects of TGF- $\beta$ signalling inhibition with galunisertib (LY2157299) in hepatocellular carcinoma models and in ex vivo whole tumor tissue samples from patients. Oncotarget 2015, 6, 21614-21627. [CrossRef] [PubMed]

185. Shain, K.H.; Dalton, W.S. Cell adhesion is a key determinant in de novo multidrug resistance (MDR): New targets for the prevention of acquired MDR. Mol. Cancer Ther. 2001, 1, 69-78. [PubMed]

186. Dickreuter, E.; Cordes, N. The cancer cell adhesion resistome: Mechanisms, targeting and translational approaches. Biol. Chem. 2017, 398, 721-735. [CrossRef] [PubMed]

187. Hazlehurst, L.A.; Dalton, W.S. Mechanisms associated with cell adhesion mediated drug resistance (CAM-DR) in hematopoietic malignancies. Cancer Metastasis Rev. 2001, 20, 43-50. [CrossRef] [PubMed]

188. Nakamura, T.; Kato, Y.; Fuji, H.; Horiuchi, T.; Chiba, Y.; Tanaka, K. E-cadherin-dependent intercellular adhesion enhances chemoresistance. Int. J. Mol. Med. 2003, 12, 693-700. [CrossRef] [PubMed]

189. Schmidmaier, R.; Morsdorf, K.; Baumann, P.; Emmerich, B.; Meinhardt, G. Evidence for cell adhesion-mediated drug resistance of multiple myeloma cells in vivo. Int. J. Biol. Mark. 2006, 21, 218-222. [CrossRef]

190. Bewick, M.A.; Lafrenie, R.M. Adhesion dependent signalling in the tumour microenvironment: The future of drug targetting. Curr. Pharm. Des. 2006, 12, 2833-2848. [CrossRef] [PubMed]

191. Makrilia, N.; Kollias, A.; Manolopoulos, L.; Syrigos, K. Cell adhesion molecules: Role and clinical significance in cancer. Cancer Investig. 2009, 27, 1023-1037. [CrossRef] [PubMed]

192. Okegawa, T.; Pong, R.C.; Li, Y.; Hsieh, J.T. The role of cell adhesion molecule in cancer progression and its application in cancer therapy. Acta Biochim. Pol. 2004, 51, 445-457. [PubMed]

193. Trzpis, M.; McLaughlin, P.M.J.; de Leij, L.M.F.H.; Harmsen, M.C. Epithelial Cell Adhesion Molecule: More than a Carcinoma Marker and Adhesion Molecule. Am. J. Pathol. 2007, 171, 386-395. [CrossRef] [PubMed]

194. Bellone, S.; Siegel, E.R.; Cocco, E.; Cargnelutti, M.; Silasi, D.A.; Azodi, M.; Schwartz, P.E.; Rutherford, T.J.; Pecorelli, S.; Santin, A.D. Overexpression of epithelial cell adhesion molecule in primary, metastatic, and recurrent/chemotherapy-resistant epithelial ovarian cancer: Implications for epithelial cell adhesion molecule-specific immunotherapy. Int. J. Gynecol. Cancer 2009, 19, 860-866. [CrossRef] [PubMed]

195. Wang, W.; Wang, L.; Mizokami, A.; Shi, J.; Zou, C.; Dai, J.; Keller, E.T.; Lu, Y.; Zhang, J. Down-regulation of E-cadherin enhances prostate cancer chemoresistance via Notch signaling. Chin. J. Cancer 2017, 36, 35. [CrossRef] [PubMed] 
196. Thiery, J.P.; Acloque, H.; Huang, R.Y.; Nieto, M.A. Epithelial-mesenchymal transitions in development and disease. Cell 2009, 139, 871-890. [CrossRef] [PubMed]

197. Marin-Aguilera, M.; Codony-Servat, J.; Reig, O.; Lozano, J.J.; Fernandez, P.L.; Pereira, M.V.; Jimenez, N.; Donovan, M.; Puig, P.; Mengual, L.; et al. Epithelial-to-mesenchymal transition mediates docetaxel resistance and high risk of relapse in prostate cancer. Mol. Cancer Ther. 2014, 13, 1270-1284. [CrossRef] [PubMed]

198. Shah, M.Y.; Martinez-Garcia, E.; Phillip, J.M.; Chambliss, A.B.; Popovic, R.; Ezponda, T.; Small, E.C.; Will, C.; Phillip, M.P.; Neri, P.; et al. MMSET/WHSC1 enhances DNA damage repair leading to an increase in resistance to chemotherapeutic agents. Oncogene 2016, 35, 5905-5915. [CrossRef] [PubMed]

199. Furukawa, Y.; Kikuchi, J. Epigenetic mechanisms of cell adhesion-mediated drug resistance in multiple myeloma. Int. J. Hematol. 2016, 104, 281-292. [CrossRef] [PubMed]

200. Jones, C.B.; McIntosh, J.; Huang, H.; Graytock, A.; Hoyt, D.G. Regulation of bleomycin-induced DNA breakage and chromatin structure in lung endothelial cells by integrins and poly(ADP-ribose) polymerase. Mol. Pharmacol. 2001, 59, 69-75. [CrossRef] [PubMed]

201. Oloumi, A.; MacPhail, S.H.; Johnston, P.J.; Banath, J.P.; Olive, P.L. Changes in subcellular distribution of topoisomerase II $\alpha$ correlate with etoposide resistance in multicell spheroids and xenograft tumors. Cancer Res. 2000, 60, 5747-5753. [PubMed]

202. Damiano, J.S.; Hazlehurst, L.A.; Dalton, W.S. Cell adhesion-mediated drug resistance (CAM-DR) protects the K562 chronic myelogenous leukemia cell line from apoptosis induced by BCR/ABL inhibition, cytotoxic drugs, and gamma-irradiation. Leukemia 2001, 15, 1232-1239. [CrossRef] [PubMed]

203. Chen, Q.; Van der Sluis, P.C.; Boulware, D.; Hazlehurst, L.A.; Dalton, W.S. The FA/BRCA pathway is involved in melphalan-induced DNA interstrand cross-link repair and accounts for melphalan resistance in multiple myeloma cells. Blood 2005, 106, 698-705. [CrossRef] [PubMed]

204. Hazlehurst, L.A.; Argilagos, R.F.; Emmons, M.; Boulware, D.; Beam, C.A.; Sullivan, D.M.; Dalton, W.S. Cell adhesion to fibronectin (CAM-DR) influences acquired mitoxantrone resistance in U937 cells. Cancer Res. 2006, 66, 2338-2345. [CrossRef] [PubMed]

205. Aslan, B.; Monroig, P.; Hsu, M.C.; Pena, G.A.; Rodriguez-Aguayo, C.; Gonzalez-Villasana, V.; Rupaimoole, R.; Nagaraja, A.S.; Mangala, S.; Han, H.D.; et al. The ZNF304-integrin axis protects against anoikis in cancer. Nat. Commun. 2015, 6, 7351. [CrossRef] [PubMed]

206. Simpson, C.D.; Anyiwe, K.; Schimmer, A.D. Anoikis resistance and tumor metastasis. Cancer Lett. 2008, 272, 177-185. [CrossRef] [PubMed]

207. Uekita, T.; Tanaka, M.; Takigahira, M.; Miyazawa, Y.; Nakanishi, Y.; Kanai, Y.; Yanagihara, K.; Sakai, R. CUB-domain-containing protein 1 regulates peritoneal dissemination of gastric scirrhous carcinoma. Am. J. Pathol. 2008, 172, 1729-1739. [CrossRef] [PubMed]

208. Shain, K.H.; Landowski, T.H.; Dalton, W.S. Adhesion-mediated intracellular redistribution of c-Fas-associated death domain-like IL-1-converting enzyme-like inhibitory protein-long confers resistance to CD95-induced apoptosis in hematopoietic cancer cell lines. J. Immunol. 2002, 168, 2544-2553. [CrossRef] [PubMed]

209. Zahreddine, H.; Borden, K.L.B. Mechanisms and insights into drug resistance in cancer. Front. Pharmacol. 2013, 4, 28. [CrossRef] [PubMed]

210. Jiang, W.G. E-cadherin and its associated protein catenins, cancer invasion and metastasis. Br. J. Surg. 1996, 83, 437-446. [CrossRef] [PubMed]

211. Johnson, J.P. Cell adhesion molecules in the development and progression of malignant melanoma. Cancer Metastasis Rev. 1999, 18, 345-357. [CrossRef] [PubMed]

212. Hazan, R.B.; Qiao, R.; Keren, R.; Badano, I.; Suyama, K. Cadherin switch in tumor progression. Ann. N. Y. Acad. Sci. 2004, 1014, 155-163. [CrossRef] [PubMed]

213. Sheridan, C.; Kishimoto, H.; Fuchs, R.K.; Mehrotra, S.; Bhat-Nakshatri, P.; Turner, C.H.; Goulet, R., Jr.; Badve, S.; Nakshatri, H. CD44+/CD24- breast cancer cells exhibit enhanced invasive properties: An early step necessary for metastasis. Breast Cancer Res. 2006, 8, R59. [CrossRef] [PubMed]

214. Zang, Z.J.; Cutcutache, I.; Poon, S.L.; Zhang, S.L.; McPherson, J.R.; Tao, J.; Rajasegaran, V.; Heng, H.L.; Deng, N.; Gan, A.; et al. Exome sequencing of gastric adenocarcinoma identifies recurrent somatic mutations in cell adhesion and chromatin remodeling genes. Nat. Genet. 2012, 44, 570-574. [CrossRef] [PubMed]

215. Li, C.; Gao, Z.; Li, F.; Li, X.; Sun, Y.; Wang, M.; Li, D.; Wang, R.; Fang, R.; Pan, Y.; et al. Whole Exome Sequencing Identifies Frequent Somatic Mutations in Cell-Cell Adhesion Genes in Chinese Patients with Lung Squamous Cell Carcinoma. Sci. Rep. 2015, 5, 14237. [CrossRef] [PubMed] 
216. Cifola, I.; Lionetti, M.; Pinatel, E.; Todoerti, K.; Mangano, E.; Pietrelli, A.; Fabris, S.; Mosca, L.; Simeon, V.; Petrucci, M.T.; et al. Whole-exome sequencing of primary plasma cell leukemia discloses heterogeneous mutational patterns. Oncotarget 2015, 6, 17543-17558. [CrossRef] [PubMed]

217. Neri, P.; Bahlis, N.J. Targeting of adhesion molecules as a therapeutic strategy in multiple myeloma. Curr. Cancer Drug Targets 2012, 12, 776-796. [CrossRef] [PubMed]

218. Tolomelli, A.; Galletti, P.; Baiula, M.; Giacomini, D. Can Integrin Agonists Have Cards to Play against Cancer? A Literature Survey of Small Molecules Integrin Activators. Cancers 2017, 9, 78. [CrossRef] [PubMed]

219. Seguin, L.; Desgrosellier, J.S.; Weis, S.M.; Cheresh, D.A. Integrins and cancer: Regulators of cancer stemness, metastasis, and drug resistance. Trends Cell Biol. 2015, 25, 234-240. [CrossRef] [PubMed]

220. Damiano, J.S. Integrins as novel drug targets for overcoming innate drug resistance. Curr. Cancer Drug Targets 2002, 2, 37-43. [CrossRef] [PubMed]

221. Hsieh, Y.T.; Jiang, E.; Shishido, S.N.; Kim, H.N.; Pham, J.; Khazal, S.; Osborne, A.; Esguerra, Z.A.; Kwok, E.; Jang, J.; et al. Effects of the small-molecule inhibitor of integrin $\alpha 4$, TBC3486, on pre-B-ALL cells. Leukemia 2014, 28, 2101-2104. [CrossRef] [PubMed]

222. Hsieh, Y.-T.; Gang, E.J.; Bonig, H.; Biediger, R.J.; Vanderslice, P.; Kim, Y.-M. The Small Molecule Inhibitor of VLA4 TBC3486 Sensitizes Resistant ALL to Chemotherapy. Blood 2012, 120, 1500.

223. Mori, Y.; Shimizu, N.; Dallas, M.; Niewolna, M.; Story, B.; Williams, P.J.; Mundy, G.R.; Yoneda, T. Anti- $\alpha 4$ integrin antibody suppresses the development of multiple myeloma and associated osteoclastic osteolysis. Blood 2004, 104, 2149-2154. [CrossRef] [PubMed]

224. Silginer, M.; Weller, M.; Ziegler, U.; Roth, P. Integrin inhibition promotes atypical anoikis in glioma cells. Cell Death Dis. 2014, 5, e1012. [CrossRef] [PubMed]

225. Nakahara, S.; Miyoshi, E.; Noda, K.; Ihara, S.; Gu, J.; Honke, K.; Inohara, H.; Kubo, T.; Taniguchi, N. Involvement of oligosaccharide changes in $\alpha 5 \beta 1$ integrin in a cisplatin-resistant human squamous cell carcinoma cell line. Mol. Cancer Ther. 2003, 2, 1207-1214. [PubMed]

226. Damiano, J.S.; Cress, A.E.; Hazlehurst, L.A.; Shtil, A.A.; Dalton, W.S. Cell adhesion mediated drug resistance (CAM-DR): Role of integrins and resistance to apoptosis in human myeloma cell lines. Blood 1999, 93, 1658-1667. [PubMed]

227. Kobune, M.; Chiba, H.; Kato, J.; Kato, K.; Nakamura, K.; Kawano, Y.; Takada, K.; Takimoto, R.; Takayama, T.; Hamada, H.; et al. Wnt3/RhoA/ROCK signaling pathway is involved in adhesion-mediated drug resistance of multiple myeloma in an autocrine mechanism. Mol. Cancer Ther. 2007, 6, 1774-1784. [CrossRef] [PubMed]

228. Schmidmaier, R.; Baumann, P.; Simsek, M.; Dayyani, F.; Emmerich, B.; Meinhardt, G. The HMG-CoA reductase inhibitor simvastatin overcomes cell adhesion-mediated drug resistance in multiple myeloma by geranylgeranylation of Rho protein and activation of Rho kinase. Blood 2004, 104, 1825-1832. [CrossRef] [PubMed]

229. Sartori, A.; Portioli, E.; Battistini, L.; Calorini, L.; Pupi, A.; Vacondio, F.; Arosio, D.; Bianchini, F.; Zanardi, F. Synthesis of Novel c(AmpRGD)-Sunitinib Dual Conjugates as Molecular Tools Targeting the $\alpha_{\mathrm{v}} \beta_{3}$ Integrin/VEGFR2 Couple and Impairing Tumor-Associated Angiogenesis. J. Med. Chem. 2017, 60, 248-262. [CrossRef] [PubMed]

230. Ley, K.; Rivera-Nieves, J.; Sandborn, W.J.; Shattil, S. Integrin-based therapeutics: Biological basis, clinical use and new drugs. Nat. Rev. Drug Discov. 2016, 15, 173-183. [CrossRef] [PubMed]

231. Scaringi, C.; Minniti, G.; Caporello, P.; Enrici, R.M. Integrin inhibitor cilengitide for the treatment of glioblastoma: A brief overview of current clinical results. Anticancer Res. 2012, 32, 4213-4223. [PubMed]

232. Stupp, R.; Hegi, M.E.; Gorlia, T.; Erridge, S.C.; Perry, J.; Hong, Y.K.; Aldape, K.D.; Lhermitte, B.; Pietsch, T.; Grujicic, D.; et al. Cilengitide combined with standard treatment for patients with newly diagnosed glioblastoma with methylated MGMT promoter (CENTRIC EORTC 26071-22072 study): A multicentre, randomised, open-label, phase 3 trial. Lancet Oncol. 2014, 15, 1100-1108. [CrossRef]

233. Vansteenkiste, J.; Barlesi, F.; Waller, C.F.; Bennouna, J.; Gridelli, C.; Goekkurt, E.; Verhoeven, D.; Szczesna, A.; Feurer, M.; Milanowski, J.; et al. Cilengitide combined with cetuximab and platinum-based chemotherapy as first-line treatment in advanced non-small-cell lung cancer (NSCLC) patients: Results of an open-label, randomized, controlled phase II study (CERTO). Ann. Oncol. 2015, 26, 1734-1740. [CrossRef] [PubMed] 
234. Vermorken, J.B.; Peyrade, F.; Krauss, J.; Mesia, R.; Remenar, E.; Gauler, T.C.; Keilholz, U.; Delord, J.P.; Schafhausen, P.; Erfan, J.; et al. Cisplatin, 5-fluorouracil, and cetuximab (PFE) with or without cilengitide in recurrent/metastatic squamous cell carcinoma of the head and neck: Results of the randomized phase I/II ADVANTAGE trial (phase II part). Ann. Oncol. 2014, 25, 682-688. [CrossRef] [PubMed]

235. Khasraw, M.; Lee, A.; McCowatt, S.; Kerestes, Z.; Buyse, M.E.; Back, M.; Kichenadasse, G.; Ackland, S.; Wheeler, H. Cilengitide with metronomic temozolomide, procarbazine, and standard radiotherapy in patients with glioblastoma and unmethylated MGMT gene promoter in ExCentric, an open-label phase II trial. J. Neuro Oncol. 2016, 128, 163-171. [CrossRef] [PubMed]

236. Mas-Moruno, C.; Rechenmacher, F.; Kessler, H. Cilengitide: The first anti-angiogenic small molecule drug candidate design, synthesis and clinical evaluation. Anticancer Agents Med. Chem. 2010, 10, 753-768. [CrossRef] [PubMed]

237. Podar, K.; Zimmerhackl, A.; Fulciniti, M.; Tonon, G.; Hainz, U.; Tai, Y.T.; Vallet, S.; Halama, N.; Jager, D.; Olson, D.L.; et al. The selective adhesion molecule inhibitor Natalizumab decreases multiple myeloma cell growth in the bone marrow microenvironment: Therapeutic implications. Br. J. Haematol. 2011, 155, 438-448. [CrossRef] [PubMed]

238. Weitz-Schmidt, G.; Welzenbach, K.; Brinkmann, V.; Kamata, T.; Kallen, J.; Bruns, C.; Cottens, S.; Takada, Y.; Hommel, U. Statins selectively inhibit leukocyte function antigen-1 by binding to a novel regulatory integrin site. Nat. Med. 2001, 7, 687. [CrossRef] [PubMed]

239. Rezaie-Majd, A.; Prager, G.W.; Bucek, R.A.; Schernthaner, G.H.; Maca, T.; Kress, H.-G.; Valent, P.; Binder, B.R.; Minar, E.; Baghestanian, M. Simvastatin Reduces the Expression of Adhesion Molecules in Circulating Monocytes From Hypercholesterolemic Patients. Arterioscler. Thromb. Vasc. Biol. 2003, 23, 397-403. [CrossRef] [PubMed]

240. Hazlehurst, L.A.; Enkemann, S.A.; Beam, C.A.; Argilagos, R.F.; Painter, J.; Shain, K.H.; Saporta, S.; Boulware, D.; Moscinski, L.; Alsina, M.; et al. Genotypic and Phenotypic Comparisons of de Novo and Acquired Melphalan Resistance in an Isogenic Multiple Myeloma Cell Line Model. Cancer Res. 2003, 63, 7900-7906. [PubMed]

241. Wagner, B.J.; Lob, S.; Lindau, D.; Horzer, H.; Guckel, B.; Klein, G.; Glatzle, J.; Rammensee, H.G.; Brucher, B.L.; Konigsrainer, A. Simvastatin reduces tumor cell adhesion to human peritoneal mesothelial cells by decreased expression of VCAM-1 and $\beta 1$ integrin. Int. J. Oncol. 2011, 39, 1593-1600. [CrossRef] [PubMed]

242. Venkataramani, V.; Küffer, S.; Cheung, K.C.P.; Jiang, X.; Trümper, L.H.P.; Wulf, G.G.; Ströbel, P. CD31 Expression Determines Redox Status and Chemoresistance in Human Angiosarcomas. Clin. Cancer Res. 2018, 24, 460-473. [CrossRef] [PubMed]

243. Podar, K.; Tonon, G.; Sattler, M.; Tai, Y.-T.; LeGouill, S.; Yasui, H.; Ishitsuka, K.; Kumar, S.; Kumar, R.; Pandite, L.N.; et al. The small-molecule VEGF receptor inhibitor pazopanib (GW786034B) targets both tumor and endothelial cells in multiple myeloma. Proc. Natl. Acad. Sci. USA 2006, 103, 19478-19483. [CrossRef] [PubMed]

244. Du Bois, A.; Floquet, A.; Kim, J.W.; Rau, J.; Del Campo, J.M.; Friedlander, M.; Pignata, S.; Fujiwara, K.; Vergote, I.; Colombo, N.; et al. Randomized, double-blind, phase III trial of pazopanib versus placebo in women who have not progressed after first-line chemotherapy for advanced epithelial ovarian, fallopian tube, or primary peritoneal cancer (AEOC): Results of an international Intergroup trial (AGO-OVAR16). J. Clin. Oncol. 2013, 31, LBA5503. [CrossRef]

245. Puhr, M.; Hoefer, J.; Schäfer, G.; Erb, H.H.H.; Oh, S.J.; Klocker, H.; Heidegger, I.; Neuwirt, H.; Culig, Z. Epithelial-to-Mesenchymal Transition Leads to Docetaxel Resistance in Prostate Cancer and Is Mediated by Reduced Expression of miR-200c and miR-205. Am. J. Pathol. 2012, 181, 2188-2201. [CrossRef] [PubMed]

246. Shou, J.; Ross, S.; Koeppen, H.; de Sauvage, F.J.; Gao, W.Q. Dynamics of notch expression during murine prostate development and tumorigenesis. Cancer Res. 2001, 61, 7291-7297. [PubMed]

247. Olsauskas-Kuprys, R.; Zlobin, A.; Osipo, C. Gamma secretase inhibitors of Notch signaling. OncoTargets Ther. 2013, 6, 943-955. [CrossRef]

248. Schott, A.F.; Landis, M.D.; Dontu, G.; Griffith, K.A.; Layman, R.M.; Krop, I.; Paskett, L.A.; Wong, H.; Dobrolecki, L.E.; Lewis, M.T.; et al. Preclinical and clinical studies of gamma secretase inhibitors with docetaxel on human breast tumors. Clin. Cancer Res. 2013, 19, 1512-1524. [CrossRef] [PubMed]

249. Brooks, S.A.; Lomax-Browne, H.J.; Carter, T.M.; Kinch, C.E.; Hall, D.M. Molecular interactions in cancer cell metastasis. Acta Histochem. 2010, 112, 3-25. [CrossRef] [PubMed] 
250. Woodward, J. Crossing the endothelium: E-selectin regulates tumor cell migration under flow conditions. Cell Adhes. Migr. 2008, 2, 151-152. [CrossRef]

251. Bevilacqua, M.P.; Nelson, R.M. Selectins. J. Clin. Investig. 1993, 91, 379-387. [CrossRef] [PubMed]

252. Azab, A.K.; Quang, P.; Azab, F.; Pitsillides, C.; Thompson, B.; Chonghaile, T.; Patton, J.T.; Maiso, P.; Monrose, V.; Sacco, A.; et al. P-selectin glycoprotein ligand regulates the interaction of multiple myeloma cells with the bone marrow microenvironment. Blood 2012, 119, 1468-1478. [CrossRef] [PubMed]

253. Yue, Z.; Wang, A.; Zhu, Z.; Tao, L.; Li, Y.; Zhou, L.; Chen, W.; Lu, Y. Holothurian glycosaminoglycan inhibits metastasis via inhibition of P-selectin in B16F10 melanoma cells. Mol. Cell Biochem. 2015, 410, 143-154. [CrossRef] [PubMed]

254. Muz, B.; Azab, F.; de la Puente, P.; Rollins, S.; Alvarez, R.; Kawar, Z.; Azab, A.K. Inhibition of P-Selectin and PSGL-1 Using Humanized Monoclonal Antibodies Increases the Sensitivity of Multiple Myeloma Cells to Bortezomib. BioMed Res. Int. 2015, 2015, 417586. [CrossRef] [PubMed]

255. Natoni, A.; Smith, T.A.G.; Keane, N.; Locatelli-Hoops, S.C.; Oliva, I.; Fogler, W.E.; Magnani, J.L.; Dwyer, M. E-Selectin Ligand Expression Increases with Progression of Myeloma and Induces Drug Resistance in a Murine Transplant Model, Which Is Overcome By the Glycomimetic E-Selectin Antagonist, GMI-1271. Blood 2015, 126, 1805.

256. Borsig, L.; Wong, R.; Hynes, R.O.; Varki, N.M.; Varki, A. Synergistic effects of L- and P-selectin in facilitating tumor metastasis can involve non-mucin ligands and implicate leukocytes as enhancers of metastasis. Proc. Natl. Acad. Sci USA 2002, 99, 2193-2198. [CrossRef] [PubMed]

257. DeAngelo, D.J.; Jonas, B.A.; Becker, P.S.; O’Dwyer, M.; Advani, A.S.; Marlton, P.; Magnani, J.; Thackray, H.M.; Liesveld, J. GMI-1271, a novel E-selectin antagonist, combined with induction chemotherapy in elderly patients with untreated AML. J. Clin. Oncol. 2017, 35, 2560. [CrossRef]

258. Bjorklund, C.C.; Baladandayuthapani, V.; Lin, H.Y.; Jones, R.J.; Kuiatse, I.; Wang, H.; Yang, J.; Shah, J.J.; Thomas, S.K.; Wang, M.; et al. Evidence of a Role for CD44 and Cell Adhesion in Mediating Resistance to Lenalidomide in Multiple Myeloma: Therapeutic Implications. Leukemia 2014, 28, 373-383. [CrossRef] [PubMed]

259. Negi, L.M.; Talegaonkar, S.; Jaggi, M.; Ahmad, F.J.; Iqbal, Z.; Khar, R.K. Role of CD44 in tumour progression and strategies for targeting. J. Drug Target. 2012, 20, 561-573. [CrossRef] [PubMed]

260. Zheng, F.-M.; Long, Z.-J.; Hou, Z.-J.; Luo, Y.; Xu, L.-Z.; Xia, J.-L.; Lai, X.-J.; Liu, J.-W.; Wang, X.; Kamran, M.; et al. A Novel Small Molecule Aurora Kinase Inhibitor Attenuates Breast Tumor-Initiating Cells and Overcomes Drug Resistance. Mol. Cancer Ther. 2014, 13, 1991-2003. [CrossRef] [PubMed] 